\title{
Left-Dislocation in Comedy (with an Appendix on Lucretius)
}

\subsection{Introduction}

Left-dislocation in comedy is by far the largest group in the corpus, consisting altogether of 77 examples. It is also the most varied in all respects, especially concerning the range of possible case combinations between the dislocated element, the relative pronoun and resumption in the main clause. Almost all the examples are from Plautus. Only five of the 77 examples of left-dislocation come from Terence (table 5). The majority of the 77 instances contain a relative clause (67 examples). There are ten examples without a relative clause, all of which come from Plautus.

TABLE 5 Left-dislocation in comedy

Author Total With a relative clause Without a rel. clause

\begin{tabular}{lrrc}
\hline Plautus & 72 & 62 & 10 \\
Terence & 5 & 5 & - \\
Total & 77 & 67 & 10 \\
\hline
\end{tabular}

In the next section (3.2), I discuss the syntax of left-dislocation in Plautus and Terence. I begin with a description of case syntax. This is followed by an analysis of relative clause syntax, whereby different types of antecedents and relative clauses are analysed. Left-dislocation with relative clause presents specific syntactic questions that are not relevant to LD without a relative clause. Therefore, dislocations without a relative clause are discussed separately (3.2.3). The final part of the syntactic description concerns syntactic functions, forms of resumptive elements and other relevant features of the matrix clause.

In section 3.3, I investigate the information structure and pragmatic organization of the passages containing left-dislocations and the function of LD in those passages. I will analyse in detail the context of each occurrence. 


\subsection{Syntactic Description of Left-Dislocation in Comedy}

In earlier research on LD in Latin, attention was paid to case syntax as an essential part of the syntax of this construction. Bach (1888: 33-34) concluded that, in Plautus, the antecedent of the relative pronoun follows the construction and case of the relative pronoun in most cases except where the main clause case extends to the antecedent as well. Bach's analysis is based on the idea that attraction of the antecedent to the case of the relative pronoun is the default strategy in Plautus.

The most pertinent discussion on the different combinations of cases is found in Lindskog (1896), where the material is divided into three groups: 1 ) case agreement between antecedent and main clause reference, 2) nominative in the antecedent and the relative pronoun as a default case and 3 ) attraction of the antecedent to the case of the relative pronoun (see 2.3 above). Lindskog naturally used different terminology, but his three categories match the threefold classification I suggest in this work-note, however, that Lindskog discussed only relative clause constructions, as he was writing about the attractio inuersa.

Havers (1926) was aware of the importance of case syntax for 'isolated nominatives', but his definition of isolated nominatives did not include constructions where the isolated element and the subsequent reference were both nominatives. This approach, which stresses the independent role of the nominative, is closely related to the way I describe thematic nominatives in this study, even if I do not share Havers's view on exluding combinations that have the nominative in both the dislocated constituent and the resumption.

In a great part of subsequent research on Latin left-dislocation little or no attention has been paid to combinations of case forms. I argue that a detailed analysis of case syntax is essential for reaching a correct understanding of the phenomenon of left-dislocation. Such an analysis makes it possible to discern the patterns in which left-dislocation occurs, establishing that case variation is not random.

Although left-dislocation can be captured cross-linguistically in a relatively simple syntactic definition (see chapter 2), in Latin, the ubiquitous presence of relative clauses complicates the situation. When we have only the dislocated constituent and the following main clause reference, there are only two options for analysis. Either the dislocated constituent anticipates the main clause case, or it is in an independent case, which in Latin is the nominative. However, when we add to this picture a relative clause that is appended to the dislocated element, the relationships between the cases become more complicated, as the intervening relative clause breaks the connection between the dislocated 
element and the matrix clause. At the same time, the dislocated constituent becomes affected by the governing force of the two clauses. ${ }^{1}$

In the following, I present, first, an overview of case distribution in comedy. The dislocated constituent can be in the nominative, accusative or dative, but the variation is not random. I have performed an analysis of the case syntax and the possible combinations of cases in the dislocated consituent, the relative pronoun and the matrix clause reference. Based on this analysis, I have divided the examples into three major groups. This division is based, first, on the case of the dislocated element (nominative, accusative or dative). Second, nominatives have been further divided into different groups according to main clause case (nominative, accusative, genitive or dative, or prepositional phrases). Dislocated constituents in the accusative and dative have been further divided into two groups according to the source of the case case form (relative pronoun or main clause reference). In addition, some neuter accusatives are grouped separately.

The nominative case can occur in a variety of syntactic contexts, but there are constraints for the use of the accusative and dative. The dislocated element in the accusative is supported either by the coreferent element in the main clause or by the relative pronoun in the accusative. Similarly, the dative in the dislocated element is supported either by the main clause reference or by the relative pronoun. ${ }^{2}$ I suggest that the most economical way of classifying left-dislocations into syntactic categories is a three-fold grouping: thematic nominatives, anticipation of main clause case and attractions.

- A dislocated element in the nominative is called a thematic nominative, regardless of what comes after it-i.e., regardless of the case of the relative pronoun and the main clause reference.

- Support from the main clause case (accusative and dative) is called anticipation.

- Support from the relative pronoun (accusative and dative) is called attraction.

Only examples where support for the accusative case of the dislocated element comes from the relative pronoun alone are defined as attractions. Those where the support comes from both the relative pronoun and the main clause (i.e., when all three references are in the same case) have been classified as anticipation. The decision to take the main clause case as decisive is based on the

1 Cf. Bach (1888: 8): 'Quodsi notio aliqua duarum enuntiationum in unam coalescentium sententiam communis est, contentio, si ita dicere licet, exoritur, utri sit attribuenda.'

2 There are two further instances where the head of the relative pronoun has been attracted to the dative, but these are not otherwise parallel to attractions. 
TABLE 6 LD with relative clauses

\begin{tabular}{lccccr}
\hline Author & $\begin{array}{c}\text { Thematic } \\
\text { nominatives }\end{array}$ & $\begin{array}{c}\text { Anticipation } \\
\text { (acc/dat) }\end{array}$ & $\begin{array}{c}\text { Attraction } \\
\text { (acc/dat) }\end{array}$ & $\begin{array}{c}\text { Neuter } \\
\text { accusatives }\end{array}$ & Total \\
\hline Plautus & 28 & 17 & 12 & 5 & 62 \\
Terence & 2 & 2 & 1 & - & 5 \\
Total & 30 & 19 & 13 & 5 & 67 \\
\hline
\end{tabular}

TABLE 7 LD without relative clauses

\begin{tabular}{lccc}
\hline Author & $\begin{array}{c}\text { Thematic } \\
\text { nominatives }\end{array}$ & $\begin{array}{c}\text { Anticipation } \\
\text { (acc/dat) }\end{array}$ & Total \\
\hline Plautus & 4 & 6 & 10 \\
\hline
\end{tabular}

Note: Neuters are classified according to the main clause case-i.e., anticipation.

existence of constructions where the support for accusative (2 occurrences) or dative ( 3 occurrences) dislocation comes from the main clause reference across an intervening relative pronoun in the nominative (e.g., Plaut. Trin. $3^{26-328}$ ).

The term 'thematic nominative' is meant to replace the old term nominatiuus pendens (and its translation 'hanging nominative'), inspired by the concept of Theme in the Functional Grammar tradition (Pinkster 1990: 37 ). ${ }^{3}$

The distribution of left-dislocation according to these criteria is presented in tables 6 and 7 .

The study of Latin left-dislocation has largely concentrated on relative clause constructions, so observations on case syntax here have likewise been made on relative clauses, but the behaviour of case syntax even in constructions without relative clauses is informative. There, we see that the dislocated constituent in most cases anticipates the main clause case. In two examples, we find a thematic nominative with a different case in the main clause reference.

Examples where both the dislocated constituent and the relative pronoun are in the nominative but the matrix clause reference is not have often, in earlier scholarship, been interpreted as attractions of the head from the main

3 As I will show below, however, the thematic nominative can be a focus constituent as well. 
clause case into the nominative. However, because of the special role of the nominative in the Latin case system, seen in its potential to occur on its own in left-dislocation (both with relative clauses and without them), I have decided to reserve the term attraction for instances where the combination head + relative pronoun is inflected in some case other than nominative. Attractions will be discussed separately below, and, in that connection, the motivation for not treating nominatives as attractions will also be specified.

Many of the dislocated constituents are in neuter (nouns or pronouns). If not otherwise indicated, I have treated neuters together with the appropriate syntactic categories and assumed that the dislocated constituent shares the same case with the relative pronoun. ${ }^{4}$

The resumptive element is most often an anaphoric pronoun (is), but it can even be a noun. In addition, the pronominal adjectives nullus and omnis are interpreted as constituting a resumptive element and, thus, a dislocation.

The total of 67 examples with relative clauses includes constructions where the antecedent of the relative pronoun is a demonstrative pronoun. ${ }^{5}$ From a purely syntactic viewpoint, these cannot be considered dislocations on an equal basis with nominal ones (see 2.2.2.2). It is, however, assumed that the pronominal construction can perform the same communicative functions as the nominal dislocations, even though their syntactic structure is different.

\subsubsection{Distribution of Cases in LD with Relative Clauses}

The attested combinations of case forms are presented in the tables below. Each table has five columns. The first gives the reference of the example, and the second records the quality of the antecedent (nominal or pronominal). In the third column, I have cited the words that precede the dislocated element. The fourth column gives the case of the dislocated constituent and the relative pronoun and the fifth the case of the resumption in the main clause. Nearly always, the order of the columns is also the linear order of the elements in the sentence. The classification has been done first with respect to the case form of the dislocated constituent and, afterwards, on the basis of the resumption in the main clause.

4 However, a separate category must be established for certain constructions with neuter accusatives. In these, the dislocated constituent must be assumed to be in the accusative together with the relative pronoun (while the main clause resumption is not in the accusative), but, due to formal similarity, it would be misleading to classify these together with attractions.

5 These include two instances of omnia and one of the quantifying pronominal aliquantillum. 
TABLE 8 Dislocated constituent in the nominative + resumption in the nominative

\begin{tabular}{|c|c|c|c|c|}
\hline Antecedent & Locus & Preceding words & Antecedent + relative & Resumption \\
\hline & & & NOM + NOM & NoM \\
\hline \multirow[t]{8}{*}{ nominal (7) } & Plaut. Aul.34-36 & et & hic qui ... senex & is \\
\hline & Plaut. Most. 858-859 & & serui qui & i \\
\hline & Plaut. Trin. 16-17 & & senes qui & $\mathrm{i}$ \\
\hline & Ter. Adelph. 22-24 & & senes qui & $\mathrm{i}$ \\
\hline & Plaut. Mil. 1292-1294 & nam & quaeuis alia [mora] quae & ea \\
\hline & Plaut. Rud.1195-1196 & & ego $\langle$ qui $\rangle$ & is \\
\hline & Plaut. Stich. 119-120 & ex malis multis & malum quod & id \\
\hline & & & NOM + NOM & NOM \\
\hline \multirow[t]{5}{*}{ pronominal (4) } & Plaut. Trin. 672 & & ille qui & is \\
\hline & Plaut. Pseud. $430-43^{2}$ & nam & istaec quae & istaec \\
\hline & Plaut. Rud.142-143 & & ill' qui & nullus \\
\hline & Plaut. Poen. 119-120 & & ille qui & is \\
\hline & & & NOM + ACC & NoM \\
\hline nominal (1) & Plaut. Cas. 654-655 & & tua ancilla quam & ea \\
\hline
\end{tabular}

\subsubsection{Thematic Nominatives}

In the first instance, the group that has the dislocated constituent in the nominative has been divided into four subgroups, according to the case form of the coreferent element in the matrix clause (nominative, accusative, dative, genitive or null anaphora).

A

Dislocated Constituent in the Nominative, Resumption in the Nominative

There are twelve examples where the dislocated element and the resumption are both in the nominative (table 8). Of these, eleven have the relative pronoun in the nominative, and one has it in the accusative. ${ }^{6}$

I cite four examples in full:

6 In addition, Plaut. Men. 983 a repeats the sententia of Most. 858-859. 
(1) Phaniscus

serui qui quom culpa carent tamen malum metuont,

i solent esse eris utibiles

PLAUT. Most. 858-859

'Those slaves who fear a trashing even when they're free from guilt are generally useful to their masters.'

(2) PARdalisca $[\ldots]$

tua ancilla quam tu tuo uilico uis

dare uxorem, ea intus-

LYSIDAMUS

quid intus? quid est?

PARDALISCA

imitatur malarum malam disciplinam,

uiro quae suo interminetur

PLAUT. Cas. $655^{-6} 6{ }^{8}$

'Your slave girl, the one you want to give in marriage to your overseer, inside she-

What's she doing inside? What is it?

She's imitating the bad behavior of bad women, since she's threatening her husband.'

(3) Prologus [...]

ille qui adoptauit hunc sibi pro filio,

is illi Poeno huius patruo hospes fuit

PLAUT. Poen. 119-120

'The man who adopted this chap as his son was a family friend of that Carthaginian, the uncle of the young man.'

(4) Callipho $[\ldots]$

nam istaec quae tibi renuntiantur, filium

te uelle amantem argento circumducere,

fors fuat an istaec dicta sint mendacia

PLAUT. Pseud. $430-432$

'Well, as for those reports you get, that your lovesick son wants to swindle you out of your money, perhaps those words are lies.' 
TABLE 9 Dislocated constituent in the nominative + resumption in the accusative

\begin{tabular}{|c|c|c|c|c|}
\hline Antecedent & Locus & Preceding words & Antecedent + relative & Resumption \\
\hline & & & NOM + NOM & ACC \\
\hline \multirow[t]{5}{*}{ nominal (4) } & Plaut. Curc. 296-297 & tum & isti qui ... serui & $\begin{array}{l}\text { et datores et } \\
\text { factores omnes }\end{array}$ \\
\hline & Plaut. Cas. 222-223 & & fel quod & \\
\hline & Plaut. Asin. 237 & $\begin{array}{l}\text { quin, si tu uoles, } \\
\text { domi }\end{array}$ & serui qui & uiros \\
\hline & Plaut. Aul. 733-734 & quia & istuc facinus quod & id \\
\hline & & & NOM + NOM & ACC \\
\hline \multirow[t]{4}{*}{ pronominal (3) } & Plaut. Rud. $25^{2}$ & & hoc quod & id \\
\hline & Plaut. Trin. 136-137 & & ille qui & eum \\
\hline & Ter. Adelph. $740-741$ & & illud quod & id \\
\hline & & & NOM + NOM & ACC \\
\hline nominal (1) & Plaut. Epid. 166-167 & & plerique homines quos & eos \\
\hline
\end{tabular}

B

Dislocated Constituent in the Nominative, Resumption in the Accusative

The second group consists of examples where the dislocated element is in the nominative, but the resumption in main clause is in the accusative (table 9).

I cite two examples in full:

(5) Megaronides [...] inconciliastin eum qui mandatust tibi, ille qui mandauit, eum exturbasti ex aedibus?

PLAUT. Trin. 136-137

'Haven't you got the man who was entrusted to you into trouble and haven't you thrown the man who entrusted him to you out of his house?'

(6) Palaestra

hoc quod est, id necessarium est perpeti

PLAUT. Rud. $25^{2}$

'It's necessary to endure the present state of things.' 
TABLE 10 Dislocated constituent in the nominative + resumption in the dative

\begin{tabular}{|c|c|c|c|c|}
\hline Antecedent & Locus & Preceding words & Antecedent + relative & Resumption \\
\hline & & & NOM + NOM & DAT \\
\hline \multirow[t]{5}{*}{ nominal (4) } & Plaut. Capt. 813-822 & tum & piscatores qui ... quorum & eis \\
\hline & Plaut. Most. 250-251 & & mulier quae & ei \\
\hline & Plaut. Rud.1291-1292 & & ego qui & ei \\
\hline & Plaut. Pseud. 716-719 & & eius seruos qui ... qui & ei \\
\hline & & & NOM + NOM & DAT \\
\hline \multirow[t]{3}{*}{ pronominal (2) } & Plaut. Poen. 769-771 & & hi qui & his \\
\hline & Plaut. Mil. 765 & igitur & id quod & $\langle e \mathrm{ei}\rangle^{\mathbf{a}}$ \\
\hline & & & NOM + ACC & DAT \\
\hline nominal (1) & Plaut. Men. $57-59$ & & Epidamniensis ill' quem & ei \\
\hline
\end{tabular}

a Plaut. Mil. 765: igitur id quod agitur, 〈ei $\rangle$ hic primum praeuorti decet ('Then we should give priority here to what's being done'), where $\langle e i\rangle$ is an addition by Bothe. This is printed out in Lindsay and de Melo but Leo marks it with a crux.

C Dislocated Constituent in the Nominative, Resumption in the Dative In this group, the dislocated element is again in the nominative, but the resumption in the main clause this time is in the dative (table 10). There are seven dislocated constituents in the nominative with resumptions in the dative. ${ }^{7}$ Of these, six have the relative pronoun in the nominative and one in the accusative. There is also one example where all three references have different case (Plaut. Men. 57-59). ${ }^{8}$

I cite the following examples in full:

7 The sense in Ter. Andr. 987a-988a requires genitive for the detached constituent (amicita nostra ... aliquam partem). This example is discarded, however, because of the probable late date of the alternative ending to Andria, from which this example is derived (see Victor 1989).

8 I have not included Plaut. Men. arg. 1-2 Mercator Siculus quoi erant gemini filii, ei surrupto altero mors optigit because the Plautine argumenta probably stem from the 2nd century CE are are thus much later than the comedies themselves. 


\section{(7) LyCus}

hi qui illum dudum conciliauerunt mihi peregrinum Spartanum, id nunc his cerebrum uritur, me esse hos trecentos Philippos facturum lucri

PLAUT. Poen. $769-771$

'Those who a while ago procured that stranger from Sparta for me now have an itch in their brains about me making profit of these three hundred Philippics.'

(8) Gripus

istic scelestus liber est: ego qui in mari prehendi

rete atque excepi uidulum, ei dari negatis quicquam

PLAUT. Rud. 1291-1292

'That criminal is free; yet you refuse to give anything to me, who caught the trunk in the sea with my net and took it out.'

D

Dislocated Constituent in the Nominative, Resumed by a Genitive in a si Clause

There is one example where a constituent in the nominative is resumed by a genitive in the si clause-i.e., the matrix clause of the left-dislocation (table 11).

(9) Ergasilus

tum pistores scrofipasci qui alunt furfuribus sues, quarum odore praterire nemo pistrinum potest: eorum si ego quoiusquam scrofam in publico conspexero, ex ipsis dominis meis pugnis exculcabo furfures

PLAUT. Capt. $807-810$

'Next point: the millers feeding sows, who raise pigs with the husks, because of whose stench no one can go past the mill; if I see a sow of any one of them in public, I'll knock the husks out of their owners themselves with my fists.'

In (9), the matrix clause where the dislocated element pistores scrofipasci is first picked up is a subordinate clause introduced by si. In the main clause, the same constituent is resumed again with the prepositional expression ex ipsis dominis, which is itself co-referent with pistores scrofipasci. 
TABLE 11 Dislocated constituent in the nominative + resumption in the genitive

\begin{tabular}{lllll}
\hline Antecedent & Locus & Preceding words & Antecedent + relative & Resumption \\
\hline & & & NOM + NOM & GEN \\
\hline nominal (1) & Plaut. Capt. 807-810 & tum & pistores scrofipasci qui & eorum \\
\hline
\end{tabular}

There are two instances where the dislocated constituent in the nominative is not picked up by a resumptive pronoun in the main clause (table 12). These are open to interpretation as LD, because the dislocated constituent as such cannot function as part of the main clause due to its case. In this sense, they are similar to attractions without resumption. There is one example where the implied case form is the genitive, and one where the implied form is the dative. ${ }^{9}$ In each of these, we must understand or supply a reference in the correct case to make the sentence understandable.

The first example is (10):

\section{(10) Tranio $[\ldots]$}

ostium quod in angiporto est horti, patefeci fores

eaque eduxi omnem legionem, et maris et feminas

PLAUT. Most. 1046-1047

'I opened the wings of the door to the garden in the alley, and I led our entire forces out, both the males and the females.'

Here, the fores belong to the ostium, though this is not made explicit. This example, however, can be alternatively interpreted as a nominal resumption, whereby fores takes up ostium.

In Plaut. Rud. 1240-1241, a dative is expected to go with licet (ille qui consulte, docte atque astute cauet, diutine uti bene licet partum bene, 'The man who is on his guard wisely, cleverly, and astutely can for a long time make use of what he's gained appropriately.'). A genitive or a dative complement is not an

9 Hahn (1964: 133-134) thinks that constructions with missing (implied) datives are not easily interpreted and should perhaps be classified as anacolutha. In addition to Plaut. Rud. 12401241, she refers to an example in Lucilius. 
TABLE 12 Dislocated element in the nominative + no overt resumption

\begin{tabular}{|c|c|c|c|c|}
\hline Antecedent & Locus & Preceding words & Antecedent + relative & Resumption \\
\hline & & & NOM + NOM & {$[$ GEN $]$} \\
\hline \multirow[t]{2}{*}{ nominal (1) } & Plaut. Most. 1046-1047 & & ostium quod & $\varnothing+$ fores \\
\hline & & & NOM + NOM & {$[\mathbf{D A T}]$} \\
\hline pronominal (1) & Plaut. Rud. 1240-1241 & & ille qui & $\varnothing+$ licet \\
\hline
\end{tabular}

indispensable part of the clause in the same way the direct object is with transitive verbs (this applies to the case of Men. 310-312, nummum illum quem, as well, the only attraction where the element to be supplied is something other than the subject). Hence, the status of these as left-dislocation is not unambiguous. They can be classified as normal sentence-initial relative clauses (types B2 and C2 in my classification; see chapter 2.2.2) with case disagreement, if it is allowed that such constructions are possible and offer a better analysis than left-dislocation.

Finally, there is one example that has been analysed in previous studies as an object ellipsis after a nominative attraction (Plaut. Asin. 621 patronus qui uobis fuit futurus, perdidistis, with implied resumption in the accusative). I argue that this is not the correct interpretation (see 2.2.3 above; Hahn 1964:131 fn. 79 with the same point but a different conclusion).

\subsubsection{Anticipation of Main Clause Case}

I then move on to those examples where the dislocated constituent has a nonnominative case. ${ }^{10}$ Accusative

The examples are given in table 13.

In (11), all references are in the accusative, whereas (12) has the relative pronoun in the nominative between illos and eos.

10 Cf. Westbury's corpus (2014: 233), where, in 10/93 prototypical dislocations, an 'accusative marker' connects the LD with the functions of the resumptive element. 
TABLE 13 Dislocated constituent in the accusative + resumption in the accusative

\begin{tabular}{|c|c|c|c|c|}
\hline Antecedent & Locus & Preceding words & Antecedent + relative & Resumption \\
\hline & & & $\mathbf{A C C}+\mathbf{A C C}$ & ACC \\
\hline \multirow[t]{7}{*}{ nominal (6) } & Plaut. Capt.110-113 & tu & istos captiuos ... quos & is \\
\hline & Plaut. Pseud. 269 & & deos ... quos & eos \\
\hline & Plaut. Men. 678-679 & immo edepol & pallam illam ... quam & eam \\
\hline & Ter. Heaut. 130-134 & sed & gnatum unicum quem & eum \\
\hline & Plaut. Trin. 116-118 & quid tu & adulescentem quem ... qui & eum \\
\hline & Plaut. Bacch. 214-215 & etiam & Epidicum quam ... fabulam & nullam \\
\hline & & & $\mathbf{A C C}+\mathbf{A C C}$ & ACC \\
\hline \multirow[t]{8}{*}{ pronominal (7) } & Plaut. Epid. $5^{1}$ & & istanc quam & eam \\
\hline & Plaut. Capt. 941-942 & & id quod & et id et aliud \\
\hline & Plaut. Persa 766 & & omnia quae & ea \\
\hline & Plaut. Aul. 144-145 & & id quod & id \\
\hline & Plaut. Mil. $35^{2}$ & sed ego & hoc quod & \\
\hline & Plaut. Men. 162 & & id ... quod & id ... id \\
\hline & Plaut. Poen. 391 & & omnia illa quae & ea \\
\hline & & & $\mathrm{ACC}+\mathrm{NOM}$ & ACC \\
\hline \multirow[t]{2}{*}{ nominal (1) } & Ter. Eun. $95^{1}$ & dicam & uirginem istam quae datast & eam \\
\hline & & & $\mathrm{ACC}+\mathrm{NOM}$ & ACC \\
\hline \multirow[t]{2}{*}{ pronominal (1) } & Plaut. Asin. $5^{27}$ & & illos qui & eos \\
\hline & & & $\mathbf{A C C}+\mathbf{A B L}$ & ACC \\
\hline nominal (1) & Plaut. Most. 116o-1162 & & $\begin{array}{l}\text { faenus, sortem sumptumque } \\
\text { omnem qui }\end{array}$ & omnia \\
\hline
\end{tabular}

(11) Menaechims

immo edepol pallam illam, amabo te, quam tibi dudum dedi, mihi eam redde

PLAUT. Men. 678-679

'No, please return that mantle I gave you a while ago.' 
(12) Cleareta [...]

illos qui dant, eos derides; qui deludunt deperis

PLAUT. Asin. 527

'You laugh at those who give, and those who trick you you love.'

(13) Hegio

quod bene fecisti referetur gratia. id quod postulas, et id et aliud quod me orabis impetrabis

PLAUT. Capt. 941-942

'For your kindness toward us you'll receive thanks. What you're requesting, this and anything else you ask me for, you'll get it.'

As can be seen from table 13, in most of these constructions, the relative pronoun is in the accusative as well, only twice in the nominative and once in the ablative (qui in Most. 116o-1162). The accusative is thus usually supported by two further occurrences of the same case in the same sentence. These examples could be called attractions as well, but, due to reasons given in 3.2.1.3 below, I prefer to see in them an anticipation of the main clause case (or possibly the combined effect of both the relative clause and the main clause).

G Dislocated Constituent in the Dative, Resumption in the Dative

In this small group (table 14), the dislocated element is in the dative. There is no ambiguity here concerning the support for the dative case in the dislocation, because the intervening relative clause always begins with a relative pronoun in the nominative.

Here is one example in full:

(14) Lysiteles

adulescenti hinc genere summo, amico atque aequali meo, minus qui caute et cogitate suam rem tractauit, pater, bene uolo ego illi facere, si tu non neuis

PLAUT. Trin. $326-328$

'If you're not against it, father, I want to do a good turn to this young chap from a family of the highest standing, a friend and contemporary of mine, who hasn't handled his affairs very cautiously and thoughtfully.' 
TABLE 14 Dislocated constituent in the dative + resumption in the dative

\begin{tabular}{|c|c|c|c|c|}
\hline Antecedent & Locus & Preceding words & Antecedent + relative & Resumption \\
\hline & & & DAT + NOM & DAT \\
\hline \multirow[t]{3}{*}{ nominal (3) } & Plaut. Trin. $3^{26-328}$ & & adulescenti ... qui & illi \\
\hline & Plaut. Bacch. $3^{85}-3^{87}$ & et ita esse arbitror & homini amico qui & ei \\
\hline & Plaut. Poen. $64-67$ & & illi seni qui & $\langle\mathrm{ei}\rangle^{\mathbf{a}}$ \\
\hline
\end{tabular}

a This correction goes back to Acidalius (16th century) and is printed by Leo, Lindsay and de Melo.

It should be noted that, in Plaut. Poen. 64-67, the matrix clause following the dislocated element illi seni qui is another relative clause: $\langle e i\rangle$ filius unicus qui fuerat. Another instance in comedy where the matrix clause is a subordinate clause is Capt. 807-810 (a si clause).

$\mathrm{H}$

\section{Neuter Accusatives with Case Disagreement}

Above, it was pointed out that a special group of neuter accusatives does not fit into any of the three major categories. These are collected in table 15 .

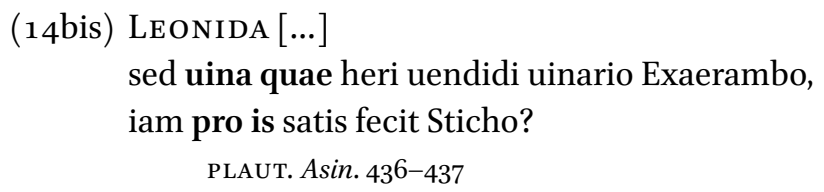

'But the wine I sold to the wine-merchant Exaerambus yesterday, has he settled with Stichus for it now?'

In neuter examples such as these, I assume, following Lehmann (1984: 351), that the antecedent shares the case of its relative pronoun. Hence, all five combinations of antecedent and relative pronoun are in the accusative. However, because of the formal similarity of neuter nominative and accusative, it would be misleading to classify these as attractions.

\subsubsection{Attraction of Antecedent (Attractio Inuersa)}

Finally, there are 13 dislocations in a non-nominative case where the case is not supported by the resumption (explicit or implicit) in the matrix clause but where it is, instead, supported by the case of the relative pronoun. These are called attractions. This group includes examples without an overt resumptive element. On this basis, attractions without a resumptive pronoun are inter- 
TABLE 15 Neuter accusatives with case disagreement

\begin{tabular}{|c|c|c|c|c|}
\hline Antecedent & Locus & Preceding words & Antecedent + relative & Resumption \\
\hline & & & ACC & PREP. PHRASE \\
\hline \multirow[t]{4}{*}{ nominal (3) } & Plaut. Asin. 436-437 & sed & uina quae & pro is \\
\hline & Plaut. Mil. 140-143 & nam & unum conclaue quod ... quo & in eo conclaui \\
\hline & Plaut. Mil. 1114-1115 & & istuc quod ... consilium & de ista re \\
\hline & & & ACC & NOM \\
\hline \multirow[t]{2}{*}{ pronominal (2) } & Plaut. Most. $840-841$ & & haec quae & ea \\
\hline & Plaut. Capt.136-137 & foris & aliquantillum ... quod & id \\
\hline
\end{tabular}

preted as left-dislocation. The difference in case form between the antecedent and the matrix clause reference means that the antecedent cannot be part of its main clause. Of these 13 examples, 12 are in the accusative and one in the dative.

I Dislocated Constituent in the Accusative or Dative, Resumption in Some other Form

The examples are given in table 16 .

There is considerable variation in the form of the resumption or implied resumption in the main clause. In three examples, there is a null anaphora of the subject in the main clause. These can be labelled the very basic type of attractio inuersa: had the attraction not taken place, the resulting sentence would contain nothing out of the ordinary ( ${ }^{*}$ Naucrates quem ... non erat).

\section{(15) Amphitruo}

Naucratem quem conuenire uolui in naui non erat PLAUT. Amph. 1009

'I wanted to meet Naucrates, but he wasn't on the ship.'

The other two are Plaut. Bacch. 935-936 (nam ego has tabellas opsignatas, consignatas quas fero, non sunt tabellae) and Ter. Eun. 652-653 (eunuchum quem dedisti nobis quas turbas dedit). In each case, the dislocated element is the subject of the following main clause.

In another three examples, there is an overt subject in the main clause, the personal pronoun ego. Hence, the antecedent of the relative pronoun, though 
TABLE 16 Dislocated constituent in the accusative or dative + resumption in some other form

\begin{tabular}{|c|c|c|c|c|}
\hline Antecedent & Locus & Preceding words & Antecedent + relative & Resumption \\
\hline & & & $\mathrm{ACC}+\mathbf{A C C}$ & $\begin{array}{l}{[\text { NOM }] / \text { GEN }} \\
\text { DAT / }[\text { ABL }]\end{array}$ \\
\hline \multirow[t]{10}{*}{ nominal (9) } & Plaut. Amph. 1009 & & Naucratem quem & $\varnothing[\mathrm{NOM}]$ \\
\hline & Plaut. Bacch. $935^{-936}$ & nam ego & has tabellas ... quas & $\emptyset[\mathrm{NOM}]$ \\
\hline & Ter. Eun. $65^{2-6} 53$ & & eunuchum quem & $\emptyset[\mathrm{NOM}]$ \\
\hline & Plaut. Capt.1-2 & & $\begin{array}{l}\text { hos quos uidetis ... captiuos } \\
\text { duos }\end{array}$ & hi \\
\hline & Plaut. Pseud. $5^{26-529}$ & em ... dolos & tibicinam illam ... quam & ea \\
\hline & Plaut. Rud. 1064-1066 & ita ut occepi dicere & illum quem ... lenonem & eius \\
\hline & Plaut. Poen. $644-645$ & & hunc chlamydatum quem & ei \\
\hline & Plaut. Men. $310-312$ & si me consulas & nummum illum quem & $\emptyset[\mathrm{ABL}]$ \\
\hline & Plaut. Epid. 448-449 & sed & $\begin{array}{l}\text { istum quem ... Periphanem } \\
\text { Plothenium }\end{array}$ & $\varnothing[\mathrm{NOM}]$ \\
\hline & & & $\mathbf{A C C}+\mathbf{A C C}$ & [NOM] / NOM \\
\hline \multirow[t]{4}{*}{ pronominal (3) } & Plaut. Curc. 419 & sed & istum quem & $\emptyset[\mathrm{NOM}]$ \\
\hline & Plaut. Trin. 985-986 & quia & illum quem & $\varnothing[\mathrm{NOM}]$ \\
\hline & Plaut. Pseud. 592 & sed & hunc quem & hic \\
\hline & & & DAT + DAT & Nом \\
\hline pronominal (1) & Plaut. Truc. $742-745$ & & illis quibus & $\mathrm{i}$ \\
\hline
\end{tabular}

co-referent with the main clause subject, is not the subject but the subject complement of ego sum (cf. Hahn 1964: 134). Because of this, these examples, too, do not contain repetition, and the only nonstandard feature is the attraction of the antecedent to the accusative.

(16) LYCo [...]

sed istum quem quaeris ego sum

Plaut. Curc. 419

'But I am the man you're looking for.'

The other two instances of this type are Plaut. Epid. 448-449 (sed istum quem quaeris Periphanem Plothenium ego sum) and Plaut. Trin. 985-986 (quia illum quem ementitus es, ego sum ipsus Charmides, quem tibiepistulas dedisse aiebas). 
In the next group, the dislocated constituent is again the subject of the main clause, but here it is picked up by a resumptive pronoun. The first example has an interrogative main clause:

(17) Pseudolus $[\ldots]$

sed hunc quem uideo, quis hic est qui oculis meis obuiam ignobilis obicitur?

PLAUT. Pseud. 592

'But who is this unknown person whom I see, who is thrown in the way of my eyes?'

The other example is Plaut. Capt. 1-2 (hos quos uidetis stare hic captiuos duos, illi quia astant, hi stant ambo, non sedent). It should be noted that the pronoun hic is used in these two passages in both the dislocated element and the resumption.

The analysis of those four examples above (Plaut. Curc. 419; Plaut. Trin. 985986; Plaut. Pseud. 592; Plaut. Capt. 1-2), where the attracted element is a pronoun, assumes that a demonstrative pronoun can act as the antecedent of the relative pronoun. As such, it can also be attracted into the relative pronoun's case form. However, as was pointed out in 2.2.2.2, this analysis may not be correct. Instead, we should identify here an autonomous relative clause modified by a pronominal attribute. According to this interpretation, there is no attraction; the pronominal attribute simply takes the case of its head, as is normal with attributes, this being the case of the relative pronoun in the autonomous relative clause. If this is the case, the two examples cited above (istum quem and istum quem ... Periphanem Plothenium) should receive different structural analyses despite their superficial similarity, because the first one (istum quem) has an autonomous relative clause and the second one an adnominal one modifying the head noun Periphanem Plothenium. ${ }^{11}$

Finally, there are instances where the resumption has a non-nominative case. These are once each in the genitive (18), dative (19) and ablative (20), with one ablative implied (21). I cite all of these examples below:

\author{
(18) Trachalio \\ ut nequitur comprimi!
}

11 Hahn (1964: 135 fn. 104) notes that Periphanem Plothenium in istum quem ... Periphanem Plothenium can be taken as an apposition to the antecedent istum. 
ita ut occepi dicere, illum quem dudum $\langle\mathrm{e}$ fano foras $\rangle$

lenonem extrusti, hic eius uidulum eccillum 〈tenet〉

PLAUT. Rud. 1064-1066

'How impossible it is to restrain him! As I began to say, look, this chap's holding that trunk of that pimp you threw out of the temple not long ago.'

(19) Advocati

hunc chlamydatum quem uides,

ei Mars iratust

PLAUT. Poen. 644-645

'This man in a cloak you can see, Mars is angry with him.'

(20) Pseudolus

em ab hoc lenone uicino tuo

per sycophantiam atque per doctos dolos

tibicinam illam tuos quam gnatus deperit,

ea circumducam lepide lenonem

PlAut. Pseud. 526-529

'Here you go: this neighbour of yours, the pimp, I'll wittily swindle him out of that flute girl your son loves through trickery and clever guiles.'

In (20), the construction is circumduco with the accusative of the person being deceived (leno) and ablative of the person or thing (the girl, ea) which the person is about to lose as the result of the trick.

\section{(21) Cylindrus \\ si me consulas}

nummum illum quem mihi dudum pollicitu's dare, iubeas si sapias porculum adferri tibi

PLAUT. Men. 310-312

'If you ask me, for that sesterce you promised to give me a while ago, you'd have a piglet brought for yourself if you're smart.'

In (21), an ablative referring to nummus is expected to complete the thought ('you should buy a pig with the coin you promised to give me'). 
TABLE 17 Antecedents of relative pronoun in attractio inuersa

\begin{tabular}{llll} 
Non-modified noun & Personal name & $\begin{array}{l}\text { Pronominal attribute }+ \\
\text { noun }\end{array}$ & Pronoun \\
\hline eunuchum & istum ... Periphanem & hos captiuos & istum \\
& Plothenium & $\begin{array}{l}\text { has tabellas } \\
\text { hunc chlamydatum } \\
\text { illum quem lenonem } \\
\text { nummum illum }\end{array}$ & $\begin{array}{l}\text { hunc } \\
\text { illis }\end{array}$ \\
& & tibicinam illam & \\
& & & \\
\end{tabular}

The attracted elements (antecedents of relative pronous) can be divided into four groups: non-modified noun, personal name, noun with a pronominal attribute and pronominal antecedent (table 17). These represent the categories of antecedents in LD in comedy generally.

What possibly syntactic motivations lie behind attraction in these cases? In the majority of LD in comedy, the antecedent agrees in case with the relative pronoun (usually in the nominative). In addition to attractions, the accusative as the common case is attested in contexts of anticipation, where all three references agree in case. However, this agreement cannot be formulated as a general rule. There are seven examples where the antecedent does not agree in case with the following relative pronoun (Cas. 654-655; Epid. 166-167; Men. 57-59; Asin. 527; Trin. 326-328; Bacch. 385-387; Poen. 64-67), demonstrating that the antecedent does not necessarily agree in case with the relative pronoun. Case agreement is not required even between the pronominal antecedent and the relative pronoun, as can be seen from Asin. 527 (illos qui), where the pronominal antecedent (modifier) is in the accusative, together with the main clause reference, but the relative pronoun is in the nominative. No indicators in the syntactic context seem to account for the antecedent's case being attracted specifically in the twelve instances cited above and not in the other ones. The search for the motivation behind this phenomenon will continue in 3.4 below, where the information structure and pragmatic function of LD in comedy is analysed.

At this point, it should be noted that there is a difference in the syntax of left-dislocation between those attractions where the main clause has an overt resumption and those where such a resumption does not exist. In attractions without resumption, attraction is the only sign of left-dislocation. In the constructions that have resumption, there is in fact a double left-dislocation, 
caused by the simultaneous occurrence of resumption and attraction, which, by itself, is seen in this study to create a left-dislocation. Consider an example like (15). Here, if the case were changed from the attracted accusative to the expected nominative, the sentence would become a well-formed Latin sentence conforming even to the norms of classical Latin. However, if we take another example of the accusative attraction - say, for example, (17) - we see that we are not able to produce a standard construction just by changing the case form (*hic quem uideo, quis hic est); there remains a left-dislocation, because in these cases the attraction is followed by an overt resumption in the main clause.

Next, I discuss the constructions that could be analysed as nominative attractions. The question of the possible outcomes of the attraction has rarely been raised in earlier research. Nominatives are occasionally given as examples, too, but without any comment on the case form. However, Lindskog (1896), Havers (1926: 249-250) and Gonda (1965: 6) were of the opinion that nominatives should not be classified as attractions but rather as 'hanging' or 'isolatedemphatic' nominatives.

There are altogether 10 examples in Plautus where a combination of the dislocated element and the relative pronoun in the nominative is followed by a different case in the matrix clause and which would therefore formally qualify as nominative attractions. There are three accusatives in the matrix clause: Curc. 296-297 isti qui serui ... et datores et factores omnis; Asin. 237 domi serui qui ... uiros (both with a nominal resumption); Trin. ${ }_{13} 6-137$ ille qui ... eum. ${ }^{12}$ Resumption in the dative occurs in Most. 250-251 mulier quae ... ei; Capt. 813822 piscatores qui ... eis; Rud. 1291-1292 ego qui ... ei; Pseud. 716-719 eius seruos qui ... ei; Poen. 769-771 hi qui ... his; Mil. 765 id quod ... 〈ei $\rangle$. In addition, there is one instance of a genitive in the resumption (Capt. 807-81o pistores scrofipasci qui ... eorum).

In several of these constructions, the sentence is so long that changing the initial case form into that required by the main clause would result in a strange construction. This is why the two dislocations in Ergasilus's song in the Captiui (Plaut. Capt. 807-810 pistores scrofipasci qui ... eorum; 813-822 piscatores qui ... eis) cannot really be analysed as nominative attractions. In the Pseudolus example (Plaut. Pseud. 716-719 eius seruos qui ... ei), it is probably the combined influence of the genitive attribute eius and length of the construc-

12 The other examples of the pattern nominative (in the dislocated element) + nominative (in the relative pronoun) + accusative (in the matrix clause) are neuters where no formal difference in case can be seen (Cas. 222-223 fel quod; Aul. 733-734 istuc facinus; Rud. 252 hoc quod; Adelph. 740-741 illud quod). 
tion that rule out the possibility of an initial dative ("eius seruo qui). This was observed already by Havers. ${ }^{13}$ In some of the other examples, it is possible to imagine a construction where the dislocated constituent is in the case required by the main clause-e.g., Plaut. Most. 250-251 ( ${ }^{*}$ mulieri quae ... ei).

The only examples where there could, in theory, be a nominative attraction without resumption and thus be parallel to the eunuchum quem / istum quem pattern are Plaut. Most. 1046-1047 ostium quod (expected case genitive); Rud. 1240-1241 ille qui cauet (expected case dative). In addition, there is one instance which would formally qualify as exactly the nominative counterpart of the eunuchum quem / agrum quem type: Plaut. Asin. 621 patronus qui uobis fuit futurus perdidistis. But as I have argued above (2.2.3), patronus must be understood not as the head of the relative pronoun but rather as the subject complement of an autonomous relative clause: qui uobis fuit futurus patronus, with an ellipsis of the object pronoun in the main clause.

It becomes apparent that attractio inuersa is a small group with much internal variation. I will now look in more detail at this variation. It is possible to classify the attractions in comedy into three groups:

1) Potentially head-internal relative clauses (eunuchum quem)

2) Other clauses with relatively simple syntax and null anaphora in the main clause (pronouns and personal names)

3) Complex and unconventional constructions (mainly with resumption)

In the present corpus, there are four attractions in the accusative outside comedy. Two of these come from Cato (discussed in chapter 5.3), one from Lucretius (see 3.7) and one from Varro (5.4). The two examples from Cato are of the head-internal type (agrum quem). In other words, as eunuchum quem (Eun. 653) is from Terence, nearly all attractions that cannot be explained as autonomous head-internal relative clauses with fronted heads come from Plautus. This distribution calls into question the status of this construction in the syntactic system of Latin. In Plautus, the head-internal type is not attested at all. Instead, we find a great variation of constructions, ranging from the simple Naucratem quem conuenire uolui in naui non erat (Plaut. Amph. 10o9) to

13 Havers (1926: 249-250): 'Auch da, wo ein als Nom. klar gekennzeichnetes Relativpron. vorliegt, wie im Latein, lehne ich die bisher vielfach übliche Bezeichnung 'Attractio inversa' ab, falls der mit dem Relativum in Beziehung stehende voraufgehende Nom. als ein emphatischer gedeutet werden kann. Also in einer Stelle wie Plaut. Pseud. 718 eius seruos, qui hunc ferebat, ei os subleui modo, wo Kroll Glotta 3, 14 von Attr. inv. spricht, hatte der Sprechende m. E. nie vor, mit dem Dativ zu beginnen, der dann durch Assimilation an den Nom. qui zum Nom. geworden wäre, sondern das emphatische eius seruos drängte an den Anfang des Satzes, ehe noch dem Sprechenden klar war, dass die folgende Konstruktion eigentlich den Dativ verlangt.' 
such extreme forms as em ab hoc lenone uicino tuo per sycophantiam atque per doctos dolos tibicinam illam tuos quam gnatus deperit, ea circumducam lepide lenonem (Plaut. Pseud. 526-529). It might be said that Plautus makes use there of the 'attractive potential' of the relative pronoun. That such a potential for attraction existed in Latin more generally is testified by the constructions in Lucretius and Varro as well as by its appearance later in the history of Latin. ${ }^{14}$

Of the ten examples in comedy where the dislocated constituent in the nominative (excluding the neuters) is followed by resumption in some other case and which would therefore qualify as nominative attractions, only three allow for analysis as a head-internal relative clause (Most. 250-251 mulier quae; Asin. 237 domi serui qui; without explicit resumption, Most. 1046-1047 ostium quod).

The nominative case has the potential to indicate a dislocated element even in instances where neither the relative pronoun nor the reference in the main clause are in the nominative (Plaut. Epid. 166-167; Plaut. Men. 57-59; without a relative clause, Plaut. Pseud.64-71). There is a clear difference here compared to the behaviour of the accusative case, the use of which is always motivated either by the function of the coreferent element in the main clause or by the attraction induced by the case of the relative pronoun. Therefore, it seems best to restrict the term attractio inuersa to cases where the dislocated constituent is in the accusative or the dative and precedes a relative pronoun in the relevant case. It would not be economical to explain combinations of a dislocation in the nominative together with the relative pronoun in the nominative as attractions. ${ }^{15}$

Finally, there is one instance that is clearly an attraction into the dative and that fits the pattern of attractions seen above in the accusative group.

\section{(22) Astaphium}

quia pol mauelim

mihi inimicos inuidere, quam med inimicis meis;

nam inuidere alii bene esse, tibi male esse, miseria est. qui inuident, egent; illis quibus inuidetur, $\mathrm{i}$ rem habent

PLAUT. Truc. $742-745$

\footnotetext{
14 Cf. Petr. 134.7 hunc adulescentem quem uides malo astro natus est; $A E$ 1964, 16o = AE 1986, 166b amicum hunc quem speraueram mi esse, ab eo mihi accusatores subiecti et iudicia instaurata.

15 Hahn (1964: 133-134) notes that, if the antecedent and relative pronouns are in the accusative and the resumption in the nominative is not expressed, then the syntax is regular, because the subject in Latin can in fact be left unexpressed (e.g., resumption in the verbal ending or understanding the whole relative clause as the subject).
} 
'Because I'd prefer my enemies envying me to me envying my enemies: it's wretchedness to envy another having a good time, having a bad time yourself. Those who envy are in need; those who are envied have money.'

In addition, there are two other examples where the antecedent has clearly been attracted to the case of the relative pronoun. In other respects, however, they do not conform to the type attractio inuersa. For example, both contain a mention of the referent preceding the attracted constituent, qui in (23) and $t e$ in (24). Therefore, they are not defined here as LD constructions. In (23), the attracted antecedent is preceded by a relative pronoun in the nominative:

\section{(23) Stratippocles}

quid illum facere uis, qui, tibi quoi diuitiae domi maxumae sunt, is nummum nullum habes nec sodali tuo in te copia est PLAUT. Epid. 329-330

'What do you want him to do? You, who have enormous riches at home, don't have a single coin for your chum, and he doesn't have any assistance in you.'

\section{(24) Megadorus}

ego te hodie reddam madidum, si uiuo, probe, tibi quoi decretum est bibere aquam

PLAUT. Aul. 573-574

'I'll get you properly soaked today, as truly as I live, you with your decision to drink water.'

These are undoubtedly true attractions in the sense that the case form of tibi in both instances must be governed by the following relative pronoun in the dative. However, I would hesitate allocating them into the same group with the other examples of attractio inuersa. I conclude that the dative attraction is an exception rather than any established form of expression. Examples (23) and (24) nevertheless testify to the potential of the relative pronoun to attract the preceding element into its case. ${ }^{16}$

Next, I investigate issues relevant to relative clause syntax.

16 On the construction of tibi quoi diuitiae, see Hahn (1964:137 fn. 112). 
TABLE 18 Antecedents of relative pronouns

\begin{tabular}{ccccccc}
$\begin{array}{c}\text { Personal } \\
\text { name }\end{array}$ & $\begin{array}{c}\text { Personal } \\
\text { pronoun }\end{array}$ & $\begin{array}{c}\text { Animate } \\
\text { noun }\end{array}$ & $\begin{array}{c}\text { Inanimate } \\
\text { noun }\end{array}$ & $\begin{array}{c}\text { Demonstrative } \\
\text { pronoun }\end{array}$ & $\begin{array}{c}\text { Pronominals } \\
\text { (omnis, } \\
\text { aliquantillum) }\end{array}$ & Total \\
\hline 2 & 2 & 26 & 13 & 21 & 3 & 67 \\
\hline
\end{tabular}

TABLE 19 Pronominal modifiers of nominal antecedents

ille iste hic tuus unus eius plerique quaeuis Total

\begin{tabular}{lllllllll}
\hline 6 & 6 & 4 & 1 & 1 & 1 & 1 & 1 & 21 \\
\hline
\end{tabular}

TABLE 20 Pronominal antecedents of relative pronouns

\begin{tabular}{cccccccc} 
ille & hic & iste & (is) id & ego & (omnis) omnia & others (aliquantillum) & Total \\
\hline 9 & 5 & 3 & 4 & 2 & 2 & 1 & 26 \\
\hline
\end{tabular}

\subsubsection{Relative Clause Syntax}

3.2.2.1 Types of Antecedents and Elements Preceding Them

In the corpus of 67 dislocations with relative clauses, there are two examples where the antecedent of the relative pronoun is a proper name (Plaut. Amph. 1009 Naucratem; Epid. 448-449 istum ... Periphanem Plothenium). Both of these examples appear in attractions in the accusative. The remaining antecedents are divided between animate nouns, inanimate nouns and pronouns (pronominals omnis and aliquantillum). The distribution is shown in table 18.

This means that there are, altogether, 41 nominal antecedents and 26 pronominal ones. Of the 41 nominal antecedents, 21 have a pronominal modifier, of which ille, iste and hic are most common (table 19).

The 26 pronominal antecedents are shown in table 20.

Altogether, then, a pronominal element is present in 47 of the 67 dislocations with relative clauses (21 modifiers of nouns and 26 pronominal antecedents, ille being the most common in both groups). This is well in accordance with the informational status of the LD constituents, which I will look at closer in the next section. A great part of the dislocated elements is actively present in the 
situations where they occur, and the abundance of pronouns can be viewed as a reflection of this.

There are five instances where the head noun of the relative pronoun is postponed, appearing only at the end of the relative clause. Each of these, however, is modified by a pronominal attribute. Hence, the only possible interpretation is that the noun does not belong in the relative clause (Plaut. Aul. 34-36 et hic qui poscet eam sibi uxorem senex; Curc. 296 tum isti qui ludunt datatim serui scurrarum in uia; Rud. 1065 illum quem dudum 〈e fano foras $\rangle$ lenonem extrusti; Capt. 1-2 hos quos uidetis stare captiuos duos; Epid. 448-449 istum quem ... Periphanem Plothenium). In these examples, it is not possible to rearrange the word order so that both the pronoun and the nominal head would be inside the relative clause ( ${ }^{*}$ qui hic senex; * qui isti serui; * quem illum lenonem; even *hic qui senex, etc.). Accordingly, they must all be understood as being outside the relative clause.

In one case, there is an ellipsis of the head noun (Plaut. Mil. 1293 nam quaeuis alia, quae mora est aeque, mora minor ea uidetur quam quae propter mulierem est). Here, mora must be understood as going with quaeuis alia. The word mora was mentioned on the preceding line, appearing as a subject complement in both the relative clause and the main clause. It is easy to supply it, giving quaeuis alia mora in the main clause (this has been counted as a nominal head).

A noteworthy example is Plaut. Pseud. 718-719 eius seruos qui hunc ferebat cum quinque argentiminis, tuam qui amicam hinc arcessebat, ei os subleui modo. The clause that precedes this one (qui a milite allatust modo) answers the question of what symbol Pseudolus is talking about. The genitive eius, then, refers to the soldier who brought the symbol. It is used to introduce his slave, to whom then the following relative clauses refer (qui ... ferebat, qui ... arcessebat) and who is picked up by the dative $e i$ in the main clause.

There seems to be no discernable pattern between the types of antecedents and case syntax. Pronominal antecedents occur in all major groups of case combinations.

The dislocated constituent does not necessarily open the sentence where it occurs. The tables above show the initial elements for each example of leftdislocation. The most common element preceding the LD is sed (6 times), which can be used when continuing to a new subject or line of argument. This is well in accordance with the pragmatic constellation of the passages, as explained below in 3.3 (picking up a topic that is present in the situation, expressing contrast or simply introducing a previously unmentioned entitity). ${ }^{17}$ Other particles or conjunctions occurring more than once are nam and

17 On nam and sed in thematic expression, see Somers (1994: 157). These co-occur even with Theme constituents in Cicero's letters. 
tum (each three times), quia (twice) and quid (twice). Once each are found et, igitur, immo edepol, etiam, tamquam, edepol uel, nunc, immo and neque.

In addition, the main clause subject occurs before the dislocated element four times (Plaut. Capt. 110-113 tu; Plaut. Trin. 116-118 quid tu; Plaut. Mil. 352 sed ego; Plaut. Bacch. 935-936 nam ego). In these instances, the main clause demonstrably begins before the LD. This means that, in principle, the dislocation could be a nominal phrase embedded in the subordinate clause, and the construction would be better described as a type of anacoluthon or simply as a superfluous pronoun in the main clause. ${ }^{18}$ However, the occurrence of the main clause predicate is here taken to be decisive for the beginning of the main clause. The construction in Plaut. Trin. 116-118 opens with quid tu (tu being the main clause subject) before the dislocated element, but this is continued by quin tu eum restituis after the left-dislocation. In Plaut. Asin. 237, we find a combination of quin as an emphatic adverb and the conditional clause $s i$ tu uoles. The subordinating conjunction quia is found twice (Plaut. Trin. 985986; Aul. 733-734). In these passages, the subordinate clauses are forgotten and dropped off after the LD. In addition, once, a conditional clause (sime consulas) is found alone before the dislocated element (Plaut. Men. 310-312).

The longest preceding element is found in Plaut. Pseud. 526-529 em ab hoc lenone uicino tuo per sycophantiam atque per doctos dolos. The construction is notable, with a LD of a rather complicated type (for a discussion, see below 3.3.3). Sometimes, another main clause constituent has been fronted and precedes the dislocated element (Plaut. Capt. 136-137 foris; Stich. 119-120 ex malis multis; Stich. 619-620 uel inter cuneos ferreos; Asin. 237 domi). There are, however, no examples where the dislocated constituent would be unambiguously embedded in the matrix clause and hence not classifiable as an LD (but cf. Men. 1051, cited by Pinkster 2012: 379; see also below).

\subsubsection{Head-Internal Relative Clauses}

It has been suggested in previous research (especially concerning attractio inuersa but also other forms of left-dislocation) that the whole phenomenon can, in fact, be best explained as a head fronted out of its relative clause. Because of the highly flexible word order of Latin, the linear order of words is not necessarily indicative of their place in the syntactic hierarchy. In other words, a head noun that appears before the relative pronoun in linear order may actually belong inside the relative clause. ${ }^{19}$ This would also imply that it

18 Cf. Wackernagel (2009: 79).

19 For the opposite phenomenon, the head noun postponed, appearing inside the relative 
is an autonomous relative clause, following the view of Pinkster (2012; forthc. chapter 18) - hence, basically of a different type altogether than the headexternal adnominal relative clause. In my discussion, I have initially taken the word order at face value-i.e., as a head noun occurring before the relative pronoun as an external head. In this part, I take a closer look at the structural placement of the heads.

Ultimately, there is no answer to the question of which one is a head-internal relative clause and which one is not, if the formal criteria are satisfied. This aspect has a direct influence on the definition of left-dislocation in Latin, because head-internal relative clauses are not defined as being part of LD. However, as left-dislocation in Latin is not a phenomenon with fixed and clear boundaries, it is necessary to investigate the head-internal relative clauses as well and to set those in comparison with head-external clauses. ${ }^{20}$

Left-dislocation in comedy cannot generally be explained as heads that have been fronted out of their relative clauses. This is because the head of the relative pronoun is very rarely an unmodified noun that would be compatible with placement inside the relative clause. Of the 67 dislocations with a relative clause, 47 heads of relative clauses have a pronominal modifier or are themselves pronouns (see tables 19 and 20 above). In these cases, the head cannot be part of the relative clause, because sequences like *qui ille homo are impossible. $^{21}$

In addition to the aforementioned criteria, case disagreement between the head and the relative pronoun rules out the head's placement inside the relative clause. There are seven such instances, but these are all ruled out already by one of the other criteria.

Eight examples then remain in which the head noun is potentially clauseinternal (Plaut. Trin. 17 senes qui ... i; Ter. Adelph. 22 senes qui ... $i$; Plaut. Most. 250 mulier quae ... ei; Plaut. Stich. 119 malum quod ... id; Plaut. Asin. 237 domi serui qui ... eos; Plaut. Asin. 436 uina quae ... pro is; Plaut. Most. 1046 ostium quod ...

clause, see 2.2.3 and 3.2.2.1 above. In each case, however, the presence of a pronominal attribute means that the head must be outside the relative clause.

20 Pinkster (2012; forthc. chapter 18) argues that the head-internal relative clause is an autonomomous relative clause and, hence, a different type from the head-external clause. Pinkster acknowledges the possibility that internal heads occur in clause-external position (cf. ex. 12 in Pinkster 2012); see 2.2.2.1 above.

21 See, however, Pinkster (forthc. chapter 18) for additional examples of anaphoric pronouns in relative clauses, attested from Apuleius onward. There is one early example from Plautus (Trin. 1022-1023 quorum eorum); see Pinkster (forthc. chapter 18); Touratier (1980:

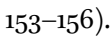


Ø; Ter. Eun. $65^{2}$ eunuchum quem ... Ø). ${ }^{22}$ Six of the dislocated constituents are in the nominative, one is a neuter accusative and one an accusative attraction. Two of the eight head nouns have a generic reference.

At this point, these potentially head-internal constructions should be compared with those that actually show the head after the relative pronoun. ${ }^{23} \mathrm{Plau}-$ tus has 22 examples of such constructions and Terence 10 examples (table 21). ${ }^{24}$

An example of a head-internal relative clause with resumption (type A1 in my classification; see 2.2.2.1) in Plautus is given in (25):

(25) et una binae singulis quae datae ancillae nobis, eae nos lauando, eluendo operam dederunt

PLAUT. Poen. 221-223

'And with us we had two slave girls each that we were given - they took care of washing and bathing us.'

An example of A1 in Terence in (26):

(26) Adhuc, Archylis, quae adsolent quaeque oportent

signa esse ad salutem, omnia huic esse uideo

TER. Andr. 481-482

'So far, Archylis, the usual and proper symptoms for a safe delivery, I see them all here.'

22 Note that at Plaut. Most. 858 serui qui cannot be a head-internal relative clause because of the quom clause that is embedded in the relative clause. Pinkster (forthc. chapter 18) classifies this example as a restrictive adnominal relative clause-hence, not an autonomous head-internal relative clause.

23 The examples of the head-internal type in Plautus have been collected by combining examples given in Bertelsmann (1885) and Lodge (1962) Lexicon Plautinum (p. 470 L: antecedens in enuntiato relatiuo insertum est). My type A1 corresponds to Bertelsmann's types A. I, 1 and A. I, 2. The figures for Terence have been produced by combining the examples from Bertelsmann and McGlynn (1963) Lexicon Terentianum (see p. 83). Examples cited by Bertelsmann that are irrelevant (e.g., changes in the text or interpretation) have been excluded.

24 Of type A2 in Plautus (head-internal relative clause without an overt resumption), 22 examples can be found and, of type A2 in Terence, 15 examples. 
TABLE 21 Head-internal relative clauses (type A1)

\begin{tabular}{|c|c|c|c|}
\hline Locus & Preceding words & Relative + head & Resumption \\
\hline \multicolumn{4}{|c|}{ CASE DISAGREEMENT } \\
\hline \multicolumn{4}{|c|}{8 (Plautus) +7 (Terence) } \\
\hline Plaut. Cist. 61o-612 & & medioxumam quam ... uxorem & ex ea \\
\hline Plaut. Mil. 727-729 & & quae ... merx & ei \\
\hline Plaut. Mil. $72-74$ & ut in tabellis & quos ... latrones & ibus \\
\hline Plaut. Cist. $675^{-677}$ & & quamne ... cistellam & ea (nescio) \\
\hline Plaut. Persa 7 & & qui ... seuos & illum \\
\hline Plaut. Truc. 227-228 & & quemquem hominem & ei \\
\hline Plaut. Mil. 735 & & qui homines & is \\
\hline Plaut. Most. 416-418 & sic ut ego efficiam & quae facta & omnia \\
\hline Ter. Eun $57-5^{8}$ & & quae res & eam \\
\hline Ter. Heaut. 654-655 & & quam ... adulescentulam & ea \\
\hline Ter. Andr. 93-95 & nam & qui ... animus & ipsum \\
\hline Ter. Hec. $3^{86-388}$ & & quaeque fors fortunast & eam \\
\hline Ter. Eun. $5^{24-525}$ & nisi si illa forte & quae ... paruola soror & hanc \\
\hline Ter. Andr. $481-482$ & Adhuc Archylis & quae ... signa & omnia \\
\hline Ter. Phorm. 88 & & in quo haec discebat ludo & ei loco \\
\hline
\end{tabular}

\section{NEUTERS}

3 (Plautus)

\begin{tabular}{|c|c|c|c|}
\hline Plaut. Persa 114-115 & mane & quod ... negotium & id \\
\hline Plaut. Cas. 100-101 & quin potius & quod ... negotium & id \\
\hline Plaut. Amph. $4 \mathrm{O} 2$ & & quod ... uitium & id \\
\hline
\end{tabular}

\section{CASE AGREEMENT \\ 11 (Plautus) +3 (Terence)}

\section{Plaut. Stich. 58-59}

Plaut. Curc. 531

Plaut. Curc. 557

Plaut. Poen. 221-223

Plaut. Amph. 947-948

Plaut. Pseud. 767-770

Plaut. Merc. 93-94

Plaut. Capt. 358

Plaut. Amph. 532

Plaut. Aul. 790

Plaut. Pseud. 318-319

Ter. Phorm. 46o-461

Ter. Hec. 72-73

Ter. Adelph. 854 et una binae singulis ut

ubi

nam

quia pol

is

iniuriam est ... aut

i ergo intro qui ... seruos homo

quoi homini

quoi homini

quae datae ancillae

quae ... uota

quoi ... puero

quas merces

quod ... beneficium

qua nocte

qui homo

qua opera

quod ... consilium

qua uia

et quoi rei est seruos is

ei

ei

eae

ea

illi

omnis

gratia ea est grauida eadem nullust una opera id eadem ei rei nunc sumamus diem 
The combination of a relative pronoun and a head noun can be (and often is) in a case different from that of the main clause resumption. It is even possible for neither reference to be in the nominative, especially when an oblique case is shared by the two references. These examples include constructions where a conjunction precedes the relative clause (ubi, quia, quin). For left-dislocation, constructions beginning with conjunctions are borderline cases but have nevertheless been included (conjunctions quia and quid are attested with dislocations). ${ }^{25}$

The head-internal relative clause is a subtype of the autonomous relative clause (Pinkster 2012; forthc. chapter 18). This type of relative clause functions at the level of the clause, as opposed to the head-external adnominal one, which functions at the level of the noun phrase. This means that the headinternal type can be used in a greater variety of syntactic contexts than leftdislocation can. For example, the head-internal type often has a subordinate clause as its matrix clause. There are three instances of such relative clauses in an $u t$ clause and one in a nisi si clause. In addition, in one case, the autonomous relative clause is the subject complement in an impersonal copula construction (Ter. Hec. 72-73 iniuriam est ... qua uia ... eadem). It is unclear to what extent the word order is optional in such embedded constructions-i.e., whether it is possible to front the head out of the relative clause, if the latter is embedded. ${ }^{26}$

We will return to the similarities and differences between the relative clause types below in section 3.5, where the information structure and pragmatic organization of LD and related constructions will be discussed. It will be possible to make certain distinctions concerning typical patterns of pragmatic organization for each type.

\subsubsection{Restrictive and Non-restrictive Relative Clauses}

The adnominal relative clause in Latin can be either restrictive or non-restrictive. In my corpus of LD in comedy, a great majority of relative clauses are restrictive. With pronominal antecedents, a restrictive relative clause is the only possible option, but restrictive relative clauses predominate even with nominal antecedents. The definition of a relative clause as restrictive or non-

25 In addition, dislocations are preceded several times by sed, nam and tum; cf. 3.2.2.1. On the other hand, two A1-type examples include nam but none have sed or tum. Does this reflect the pragmatic status of left-dislocation vs. Al?

26 For Plautus, even this seems to have been possible, to judge from (12) in Pinkster (2012: 379), quin modo eripui, homines qui ferebant te sublimen quattuor, apud hasce aedis (Plaut. Men. 1051), but such instances are probably exceptional and would have the feel of an anacoluthon. 
restrictive is not always straightforward. The restrictive relative clause is 'essential for a correct understanding' of its referent (Pinkster 2012) and 'reduces the number of possible referents of the heads' (Pinkster forthc. chapter 18). Non-restrictive relative clauses occur in thirteen instances, with the following heads: pistores (Plaut. Capt. 807), piscatores (Plaut. Capt. 813), gnatum unicum (Ter. Heaut. 130), adulescentem (Plaut. Trin. 116), adulescenti (Plaut. Trin. 326), homini amico (Plaut. Bacch. 386), Naucratem (Plaut. Amph. 1009), istum Periphanem (Plaut. Epid. 448), fel (Plaut. Cas. 222-223), deos (Plaut. Pseud. 269), Epidicum ... fabulam (Plaut. Bacch. 214-215), ego (Plaut. Rud. 1195, 1291). ${ }^{27}$

In the case of deos quos, dei must have existed as a group of entities in need of no further definition in the minds of Plautus and his audience. As for fel quod amarum est, a restrictive interpretation is impossible on semantic grounds. All fel is amarum, so the relative clause cannot be restrictive. Two relative clauses are attached to personal names. They must equally be defined as non-restrictive (given that these are not homonymous with another person in the play and that the relative clauses do not imply a change in the person in the sense of Pinkster forthc. chapter 18).

Often, it is unclear at first sight whether a relative clause is restrictive or non-restrictive (and whether the definition is syntactic or semantic). For example, in the following instance, the relative clause must be classified as nonrestrictive, since gnatum unicum is identifiable without it.

(27) Menedemus [...]

sumptus domi

tantos ego solus faciam? sed gnatum unicum, quem pariter uti his decuit aut etiam amplius, quod illa aetas magis ad haec utenda idoneast, eum ego hinc eieci miserum iniustitia mea!

TER. Heaut. 130-134

'All this vast household expenditure to be for me only, while my only son, who should have shared the enjoyment equally—no, had more of itsince youth in the time for enjoyment,-I have driven the poor boy out by my injustice, mine?'

27 To these should possibly be added Epidamniensis ille (Plaut. Men. 57). Hahn (1964:136-137) is in favour of the restrictive interpretation of the Ergasilus passage (Plaut. Capt. 807 ff.), though she aknowledges the possibility of a non-restrictive interpretation, because Ergasilus probably thinks that all millers and fishmongers are what he describes. 
TABLE 22 Left-dislocation without a relative clause

\begin{tabular}{llll}
\hline Locus & Preceding words & Dislocated element & Resumption \\
\hline Plaut. Poen. 1067-1071 & & pater tuos & is \\
Plaut. Persa $63^{8}$ & tamquam & hominem & eum \\
Plaut. Bacch. 945 & & nostro seni huic stolido & ei \\
Plaut. Mil. $25^{-26}$ & edepol uel & elephanto & ei \\
Plaut. Pseud. $64-71$ & nunc & nostri amores ... oppressiounculae & harunc uoluptatum \\
Plaut. Most. 592 & immo & faenus & id \\
Plaut. Stich. 75 & & principium & id \\
Plaut. Stich. $619-620$ & uel inter cuneos ferreos & tantillum loculi & id \\
Plaut. Epid. 85 & neque & ego & $\emptyset$ [DAT with placet] \\
Plaut. Asin. 198 & & diem aquam solem lunam noctem & haec \\
& & &
\end{tabular}

Similar cases are Plaut. Trin. 116-118 (adulescentem quem), 326-328 (adulescenti ... qui). I have classified all three as non-restrictive.

\subsubsection{Left-Dislocation without a Relative Clause}

The final group to be discussed is left-dislocation without a relative clause. There are ten such examples, presented in table 22.

The first of these, (28), has both a dislocated element and a resumption immediately following, in the nominative.

(28) Hanno

factum, quod $\langle$ ego $\rangle$ aegre tuli.

nam mihi sobrina Ampsigura tua mater fuit;

pater tuos, is erat frater patruelis meus,

et is me heredem fecit quom suom obiit diem,

quo me priuatum aegre patior mortuo

PLAUT. Poen. 1067-1071

'Yes, which was hard for me: your mother, Ampsigura, was my second cousin; your father, he was my first cousin, and he made me his heir when he passed away: it's hard for me to be deprived of him through his death.'

In (29), both references are in the dative: 
(29) nostro seni huic stolido, ei profecto nomen facio ego Ilio PLAUT. Bacch. 945

'This stupid old man of ours, I'll definitely give him the name of Ilium.'

We notice that, in left-dislocation without a relative clause, the two references usually agree in case (once in the nominative, twice in the accusative and twice in the dative, as well as three neuters). The only example of case disagreement is $(30)$.

In (30), the dislocated element (in a love letter) is a long list of nouns in the nominative that are then picked up by the genitive harunc uoluptatum. ${ }^{28}$

\section{(30) Pseudolus}

'nunc nostri amores, mores, consuetudines

iocus, ludus, sermo, suauisauiatio, compressiones artae amantum corporum teneris labellis molles morsiunculae, nostr[or] um orgiorum $\langle$ osculat $\rangle$ iunculae, papillarum horridularum oppressiounculae

harunc uoluptatum mi omnium atque itidem tibi distractio, discidium, uastities uenit, nisi quae mihi in te est aut tibi est in me salus.'

PLAUT. Pseud. 64-71

'Now, as for our passions, ways, and habits, jest, play, chat, and sweet kisses, the tigh squeezing of loving bodies, the tender little bites with gentle lips, the little kisses of our secret meetings, the little pinchings of firm little breasts, a disseverance, disunion, and desolation of all these pleasures is coming to me and in the same way to you, unless I have some help in you or you in me.'

Other lists are given in Plaut. Asin. 198 (without a relative clause) and Most. 1160-1162 (with a relative clause).

28 It should be noted that the genitive, being an adnominal case, is not of the same status as a resumptive case with the accusative and dative (which are cases of verbal complements). 
TABLE 23 Resumptive elements

is hic iste ille nullus nominal omnis ${ }^{\mathrm{a}} \emptyset$ Total

$\begin{array}{lllllllll}46+7 & 3+1 & 1 & 1 & 2 & 4+1 & 1 & 9+1 & 77\end{array}$

a The inclusion of omnis as a resumption is not unproblematic (see Probert and Dickey 2016: $391 \mathrm{fn}$. 7), but I have decided to include it. There are not many such examples in the corpus.

In Plaut. Epid. 85, there is no overt resumption, but a dative (mihi) is expected to go with placet (a pattern that agrees with Plaut. Rud. 1240-1041 ille qui ... licet). We have seen ellipsis twice now with dative complements. ${ }^{29}$

\subsubsection{Further Observations on Syntax}

\subsubsection{Form of Resumption}

In 67 of the 77 cases of dislocation, there is an overt resumptive element in the main clause (in 58 of the 67 with relative clauses). Table 23 shows the distribution of different types of resumptive elements (those given after + are in instances without relative clauses).

As can be seen from table 23, is is used in the overwhelming majority of cases. Hic is found three times with relative clauses, in each of which instance the dislocated constituent consists of the same pronoun hic, when there is a relative clause (Plaut. Poen. 769-77o hi qui ... his; Pseud. 592 hunc quem ... hic; Capt. 1-2 hos quos ... hi). In addition, iste (Pseud. 430-432 in the combination istaec-istaec) and ille (Plaut. Trin. ${ }^{26-327}$, adulescenti ... qui ... illi) occur once each. Five times, the resumption contains a nominal element (Plaut. Mil. 140143 unum conclaue ... in eo conclaui; Curc. 296-297 isti qui ludunt ... serui ... et datores et factores omnis subdam sub solum; Asin. 237 serui qui sunt ... uiros; Mil. 1114-1115 istuc quod ... consilium ... de ista re; Pseud. 64-71 nostri amores, mores, consuetudines ... harunc uoluptatum). ${ }^{30}$ The first of these (Mil. 140-143) is a straightforward case where the same noun conclaue is repeated in the resumption. In the Curculio passage, et datores et factores must refer to the serui who are playing. It is thus a nominal resumption but with a noun different from that in the LD. The same applies to the Asinaria example. In these two passages, the

29 See further sub-section 5.3.3 for rex Iuba ... uisum est in Sallust (another elliptical dative).

30 In addition, there is a nominal element in the second resumption in Capt. 807-810 pistores scrofipasci qui ... eorum ... ex ipsis dominis. 
nominal resumptions are open to an alternative interpretation, as second coreferent objects.

The resumptive pronoun is always placed preverbally, and the same applies to the nominal resumptions. There seem to be no discernible patterns between the form of resumption and case syntax.

Finally, there are ten examples without any coreferent element in the main clause. Seven of these are accusative attractions, discussed already in 3.2.1.3. Two other examples with relative clauses were discussed in 3.2.1.1 (E), and one example without a relative clause in 3.2.3.

\subsubsection{Syntactic Functions and Matrix Clauses}

The tables presented above are an easy way to illustrate the variety in case agreement. However, they do not necessarily tell us all about the role of the constituent in each clause. Therefore, I present here an analysis of the syntactic functions of the relative pronoun and the anaphoric reference in the matrix clause. There is difference between these references. The matrix clause reference expresses the proposition and takes the discourse forward. In the matrix clause, we can observe the actual role of the dislocated constituent in the discourse fragment. The relative clause serves to identify the referent or characterize it in some way that is relevant to the given situation. This happens in all instances irrespective of whether the relative clause is restrictive or nonrestrictive.

Already Bach (1888: 28) noted that the relative pronoun is nearly always in the nominative or accusative. The relative pronoun is the subject in 33 instances. Of these, the relative pronoun is the subject of the copula in only eight instances.

The accusative relative pronouns are, for the most part, direct objects of the relative clause predicate (27 examples). This predicate is typically in the first or second person, and there is one impersonal construction (Plaut. Pseud. 269 quos aequom estmetuere). Third-person predicates appear, too, but in, e.g., quos deseritpudor (Plaut. Epid.166-167), the object quos, in accusative, is the psychological subject of the relative clause. In addition, the accusative can be part of an accusatiuus cum infinitiuo (AcI) construction (three examples). The remaining relative pronouns are dative complements.

All of the accusatives in attraction are direct objects of the relative clause predicate $(7 / 12$ in second person singular, $3 / 12$ in first person singular, 1/12 in second person plural, $1 / 12$ in 3 rd person singular, though the subject there is tuos natus). This is nothing extraordinary, but there are certain expressions that occur in attractions more than once. One such case is quem uides, another quem quaeris. Here also, the semantics of the verbs are closely related to the 
action happening on the stage (see further 3.4, where attractions are discussed in greater detail). Hence, it seems that not all accusatives have, even in principle, the force to attract the antecedent into their case.

In the dative attraction illis quibus inuidetur, quibus is the dative object of inuidetur.

In the matrix clauses, the resumptive element is the subject in 19 instances ( 5 times of the copula) and a subject complement in three instances (both including elliptical uses). It is the direct object in 21 instances, one of which is the psychological subject (eos deserit pudor). The datives in main clauses are usually close to the object or contain the psychological subject in their function (e.g., with predicates praestare, surrupitur, praeuorti decet). Notably, the dislocated constituent, which is the topic in the majority of cases, is the subject of the main clause in one third of the examples (22/77 examples, if we count the subject complements as well). This is slightly surprising, given that topics are usually associated with the subject function.

In left-dislocation without relative clauses, the anaphoric element is the direct object four times, the subject twice, the dative complement three times, and a genitive attribute once.

The matrix clauses are assertions in most cases. In addition, we find questions (eum exturbasti?; quin eum restituis?; pro is satis fecit?; quis hic est?; qui eum quaeras?) as well as four exhortations (is indito; mihi eam redde; id arte ut corrigas; iubeas si sapias porculum adferri). The assertions are given in past, present as well as future tense. There is one instance of an AcI in the main clause (nisi deos ei nihil praestare). The matrix clause predicate is typically in first or third person singular or in third person plural, but the second person is also attested. In two places, the matrix clause itself is a subordinate clause (a si clause in Plaut. Capt. 807-810 and a relative clause in Plaut. Poen 64-67).

\subsubsection{Conclusion}

Here, I sum up the findings of this section. The dislocated constituent can be in the nominative, accusative or dative. The nominative can appear in all contexts, whereas the accusative and the dative must be supported by either the case of the matrix clause or that of the relative pronoun. The syntactic division into three groups was found to be an economical way to account for the syntactic variation. These three groups are 1) thematic nominatives (dislocated elements in the nominative), 2) anticipation (accusative or dative anticipating its role in the matrix clause) and 3) attraction (accusative or dative supported by the case of the relative pronoun). Pronominal modifiers of nominal antecedents are frequent. Pronominal antecedents are found in all case combinations. 
Resumption happens usually with is. In addition, hic and iste occur in combinations where the same pronoun can be found in both the antecedent and the resumption.

Attraction can occur either with or without resumption. This construction type has much variation in its syntax but, on the other hand, certain phrases occur more than once.

Left-dislocation without a relative clause, though infrequent, shows the same syntactic patters as left-dislocation with relative clause (excluding attraction): thematic nominatives and anticipation of the main clause accusative and dative. This observation, together with the fact that left-dislocation including a relative clause cannot, in most cases, be explained as a fronted head of a headinternal relative clause, supports the conclusion that left-dislocation in comedy is not caused primarily by relative clause syntax.

\subsection{Information Structure and Pragmatic Functions of Left-Dislocation in Comedy}

This chapter is about the information structure and pragmatic organization of the passages that contain LD constructions in comedy. In this part, the discussion moves from the syntactic description of $L D$ to the function it has in comic dialogue. For both dimensions, information structure and pragmatic organization, the framework and terminology has been adapted from Lambrecht (1994, 2001). The theoretical framework and the concepts and terms used in this analysis have been outlined in sub-section 2.1.2. I recapitulate the main concepts here.

Information structure refers to the status of the linguistic element in the discourse. The element may be actively present in the discourse or accessible through some other element. In dramatic texts, one way of being actively present (sometimes without a preceding verbal reference) is that the element is present on stage. On the other hand, in lively dramatic dialogue, we also find instances of dislocated elements that have not yet been mentioned in the play and are therefore Brand New elements. As for information status, the categories used in this analysis are Active, Accessible and Brand New anchored (BNA) (following Lambrecht 1994). In comedy, these are defined as follows. An element that is Active has been mentioned in the immediately preceding part of the dialogue where the element appears in a left-dislocation. Another type of Active referent is an element that is present on stage (situationally evoked). An Accessible referent has been mentioned farther back in the conversation or is an entity the identity of which is known-for example, one of the main 
characters of the play (even if not on stage). A Brand New element has not been mentioned earlier in the play and is not accessible in any other way. In comedy, when such referents occur in left-dislocation, they are always anchored in the situation, typically with the help of a restrictive relative clause. Generic statements (sententiae) are shown to be rather frequent among LD in comedy. In them, the dislocated element is not necessarily connected to the preceding or the subsequent context.

Pragmatic organization refers to the function the element has in the discourse. The two basic concepts of discourse function are topic and focus. The topic is the element about which the linguistic expression predicates something. The focus is the most salient thing that is predicated about the topic. These concepts are useful tools in pragmatic analysis, but it is clear at the onset that their application is not straightforward, and it will be difficult or pointless to identify one or both in certain constructions.

The element that is the topic in a given predication can relate to the preceding or the subsequent context in various ways. The element may not have been previously mentioned (Brand New referent) but is promoted to topic in the leftdislocation where it appears. On the other hand, the element can be Accessible or Active (and, hence, discourse-old) but not yet topical before its appearance in the LD construction. If the element is already topical, left-dislocation serves to highlight the topical referent and bring a certain amount of disruption into the conversation.

Concerning the following context, the minimal requirement of a topic is that it be the topic in the sentence where it appears. In that case, the referent disappears from the conversation after having been mentioned once. These are typically occasional remarks that do not have any impact on the play's action. Another type of topic is one where the topical element is mentioned anaphorically at least once in the immediate subsequent context, typically the next sentence after its establishment as topic.

In a clear majority of LD in comedy, the dislocated constituent is Active or Accessible in its informational status and is the topic of at least its own sentence. Typically, the constituent also remains the topic of one or two sentences after its promotion to topic via LD. Not infrequently, such a constituent continues as the topic of the ensuing dialogue.

A considerable number of LD constructions are generic statetements. They are not about any given entity in the play, but general truths about human life and mankind.

Previously unmentioned Brand New referents are thought not to be common as topics, but it has been observed that the informational status of dislocated constituents contains much variation. It seems that, due to effective 
anchoring with relative clauses, Brand New referents may appear as topics even in contexts that are not generic (cf. Lambrecht [1994:167-168], who notes that anchored Brand New referents are acceptable as topics). That we are dealing with dramatic dialogue, which is essentially a fictional and artistic language despite its close relationship with spoken registers, may have something to do with this, as was earlier suggested by Somers (1994: 154-155; see 2.1.2 above). ${ }^{31}$ Brand New referents promoted to topics via LD do not tend to remain topics beyond the sentences where they occur.

Sometimes, LD introduces a topic that is clearly contrastive. Contrastive topics are supposed to be kept apart from foci and contrastive foci, though this is not always possible.

It seems that there are occasional examples where the dislocated constituent fits the definition of a focus better than it does that of a topic. As was pointed out in section 2.1.2, the possibility of dislocated constituents that are foci in their predications is not ruled out in principle, even with the theoretical arguments presented against this possibility (Lambrecht 2001). Focused elements as dislocated constituents form a minority, and certain examples are open to more than one interpretation between the topical and focal poles of the continuum. However, there is enough to show that $\mathrm{LD}$ in Latin is not reserved exclusively to topics. Foci occurring as dislocated constituents may be Brand New referents.

Is it possible to discern recurring patterns and to show that the occurrence of LD is not a random syntactic irregularity? In the following discussion, I focus on the ways in which typical combinations of information structure and pragmatics are formed. Based on a close analysis of the combination of the dramatic and linguistic context, information structure and pragmatic function, I suggest identifying six types of left-dislocation in comedy (outlined in table 24).

Analysing discourse-related features, such as information structure and pragmatic organization, necessarily brings a certain amount of subjectivity into the discussion. Different scholars will have different opinions on what counts as Active or Topic in a given fragment of discourse.

Defining what a topic, a focus or an active referent is, at the theoretical level, is different from actually identifying them in a Latin text in a consistent way. Therefore, to make the discussion more useful and accessible, I will offer in the following analysis paraphrases of the dramatic situtations from which the examples come.

31 Somers (1994:155) states that another type where Brand New information may be found as a Theme constituent is when the information is about the text's structure, not its contents (type haec quae dicam). 
TABLE 24 Types of pragmatic organization in left-dislocation

Pragmatic category

Number of

occurrences

Active elements promoted to discourse topics

Re-activating an Accessible referent or introducing a BNA referent as

24 topic

Complex referential situations

Generic statements

Contrastive contexts

Focus

Total

It will become evident that syntactic, information structural and pragmatic factors must be considered together to accurately define how and why leftdislocation is used in Roman comedy.

\subsubsection{Active or Accessible Elements Promoted to Discourse Topics}

In the passages discussed in this section, the dislocated constituent is actively present in the conversational context and enjoys what might be called a topical status even before its appearance in the left-dislocation. It is then promoted to topic with the help of the left-dislocation. Importantly, after its occurrence as a dislocated element, it remains the topic of the dialogue for some time.

The first example comes from Casina:

\section{(31) LYSIDAMUS}

possum scire ego istuc ex te quid

negoti est?

PARDALISCA

dicam

tua ancilla quam tu tuo uilico uis

dare uxorem, ea intus-

LYSIDAMUS

quid intus? quid est?

PARDALISCA

imitatur malarum malam disciplinam, uiro quae suo interminetur

Plaut. Cas. $654-658$ 
'Can I know from you what's the matter?

I'll tell you. Your slave girl, the one you want to give in marriage to your overseer, inside she-

What's she doing inside? What is it?

She's imitating the bad behavior of bad women, since she's threatening her husband.'

In this scene with Lysidamus and Pardalisca, the latter (a slave-girl) is telling the old man Lysidamus that terrible things are happening inside the house. Lysidamus's slave girl Casina (tua ancilla) has a sword and threatens to kill her future husband. This is potentially dangerous for Lysidamus, because Lysidamus's plan is to sleep with her before she is given in marriage to his overseer Olympio. Tua ancilla (i.e., Casina) and her terrible plan have been mentioned earlier on 1l. 650-651 (malum pessumumque hic modo intus apud nos tua ancilla hoc pacto exordiri coepit). Then, on 1.655 , Pardalisca, after some hesitation, resulting from fear, resumes this topic, and re-introduces tua ancilla with a restrictive relative clause and a resumptive pronoun, $e a$. Casina and her plans, which are actually only a trick by Pardalisca, remain the topic of the dialogue between the two until l. 716, when Pardalisca leaves the scene.

The next example comes from the Menaechmi:

(32) Menaechmus

immo edepol pallam illam, amabo te, quam tibi dudum dedi, mihi eam redde

PLAUT. Men. 678-679

'No, please return that mantle I gave you a while ago.'

The mantle, palla, which Meneachmus has stolen from his wife to give to his mistress Erotium, has been the centrepiece of action and dialogue since l. 6og. In (32), Menaechmus is addressing Erotium to get back the mantle he had given her earlier. In the preceding lines, Menaechmus first asks her whether she has any idea why he has come, to which she answers in the affirmative, to get pleasure from her. Menaechmus then tells the true reason, referring to pallam illam. The mantle is the topic of the ensuing discussion (until l. 70o, when both leave the scene).

The next example comes from Pseudolus: 
(33) Callipho [...]

nam istaec quae tibi renuntiantur, filium

te uelle amantem argento circumducere,

fors fuat an istaec dicta sint mendacia

Plaut. Pseud. 430-432

'Well, as for those reports you get, that your lovesick son wants to swindle you out of your money, perhaps those words are lies.'

Callipho and Simo are discussing the unpleasant fact that people all around the city are gossiping about Simo's son's plans to set free a slave girl with whom he is in love. Callipho first expresses his deep contempt for those who spread and listen to these accusations (Pseud. 427-429 homines qui gestant quique auscultant crimina, si meo arbitratu liceat, omnes pendeant, gestores linguis, auditores auribus). He then continues to talk about the gossip and takes it up with istaec quae tibi renuntiantur, followed by a clarification ( filium ... uelle ... circumducere), after which the antecedent istaec is resumed with another occurrence of istaec. The rumour and closely related matters remain the topic until 1. 445, when Pseudolus joins the conversation and, again, from l. 481 onward.

In these three examples, we can see how LD is used by Plautus to promote an active, even topical, element to new discourse topic. In all three instances, the motivation behind using LD is clearly pragmatic. LD is essential in establishing the element as the topic of discourse, which it remains for the rest of the conversation. These examples correspond well to what Lambrecht (2001: 1073) says about the typical contexts of LD: the element's promotion to topic via LD is somehow expected (cf. Westbury 2014: 189 on the 'disruptive' potential of LD in such contexts).

In the following two examples, the dislocated elements are established as topics immediately after their first mention. The first example comes from Terence's Heautontimorumenos:

(34) Menedemus [...]

sumptus domi

tantos ego solus faciam? sed gnatum unicum, quem pariter uti his decuit aut etiam amplius, quod illa aetas magis ad haec utenda idoneast, eum ego hinc eieci miserum iniustitia mea!

TE R. Heaut. 130-134 
'All this vast household expenditure to be for me only, while my only son, who should have shared the enjoyment equally, no, had more of it, since youth in the time for enjoyment,-I have driven the poor boy out by my injustice, mine?'

In these lines the old man Menedemus reveals to his friend Chremes the cause for his self-tormenting actions. He has come to realize that it was wrong to drive his son away from home, a son who had every right to enjoy his careless life there, even more so since he is young and more capable of such enjoyment than his old father. The son had first been mentioned on 1l. 93-94 (filium unicum adulescentulum habeo). He is clearly the topic of the statement in (34), and this initial state of affairs is naturally important for the whole play.

A similar organization appears in Plautus's Trinummus:

\section{(35) Megaronides}

quid tu, adulescentem, quem esse corruptum uides

qui tuae mandatus est fide et fiduciae

quin eum restituis, quin ad frugem conrigis?

PLAUT. Trin. 116-118

'Well then? Why don't you change the young man back and bring him back to responsible behavior, when you can see that he's decadent and when he was entrusted to your faith and reliability.'

Here, Megaronides castigates his old and good friend Callicles for not taking better care of a third person's son, who had been entrusted to his care. The young man was mentioned in the preceding speech by Callicles among the matters left to his care when their master went away. The young man is established as the topic on l. 116. Megaronides asks his friend why Callicles would not try to guide the young man toward a more honourable way of life. It is his actions that are relevant here and that form a central theme in the play as a whole. In the following sentence in Megaronides's speech, the same topic continues (119 eirei operam dare te fuerat aliquanto aequius), and the young man remains the topic of the conversation between the two old men until l. 139. This passage also includes example (6o).

It is noteworthy that, in their syntactic and pragmatic organization, (34) and (35) are such close parallels, occurring as they do in two different authors.

The adulescens mentioned in the following example is the same as that in (35) above, later in the play this time: 


\section{(36) Lysiteles}

adulescenti hinc genere summo, amico atque aequali meo, minus qui caute et cogitate suam rem tractauit, pater, bene uolo ego illi facere, si tu non neuis

PLAUT. Trin. 326-328

'If you're not against it, father, I want to do a good turn to this young chap from a family of the highest standing, a friend and contemporary of mine, who hasn't handled his affairs very cautiously and thoughtfully.'

These words are spoken by the young man Lysiteles, and they serve to introduce his request to his father. The adulescens whom Lysiteles wants to help is established as the topic of the following discussion until l. 344, and again from l. 360 onward (cf. Nixon's translation, 'There's a young fellow here'). That something like a request is coming has been hinted at on 1.324 (res quaedamst quam uolo ego me abs te exorare). The depraved young man Lesbonicus was the topic of a conversation between Callicles and Megaronides in act 1, for which see (35), but is here mentioned for the first time in Act 2, after a long sung monologue by Lysiteles and a dialogue between Lysiteles and his father Philto. We may notice in this connection that, both here and in Captiui (see below), the same person or persons is given two times in an LD construction.

In the Aulularia, one of the central themes in the play is a crime (facinus) in fact, two of them but of different kinds. In the following example, istuc facinus is Accessible in the context and is the topic of the sentence.

\section{(37) Lyconides}

quia istuc facinus quod tuom

sollicitat animum, id ego feci et fateor

PlAUt. Aul. 733-734

'Because that deed which is upsetting you, well, I did it and I admit it.'

This line comes from the beginning of the famous scene between the young Lyconides and the old man Euclio. Lyconides has come to confess his criminal action, raping Euclio's daughter Phaedrium. With the above words, he introduces his confession. The crime, istuc facinus, introduced here, forms the central topic of the following discussion, though it denotes a different act for the two interlocutors. To Euclio, it refers to the gold that was stolen from him, misinterpreting Lyconides's words as a confession that it was he who stole the gold. 
In the fourth act of Miles gloriosus, Pyrgopolinices, the braggart soldier, and the slave Palaestrio have just had a meeting with Milphidippa, the 'maid' of the young 'wife' of Periplectomenus (both women are, in reality, prostitutes hired to play the trick on Pyrgopolinices). The plan is to persuade the soldier that the young wife is madly in love with her and then get the soldier to get rid of her mistress Philocomasium, so that she can return to her true lover Pleusicles.

\section{(38) Pyrgopolinices \\ istuc quod das consilium mihi, te cum illa verba facere de ista re volo \\ PLAUT. Mil. 1114-1115}

'As for the advice you give me, I want you to talk to her about that.'

The advice, istuc consilium, here refers to Palaestrio's plan to get rid of Philocomasium in a friendly way so as to let her keep what the soldier has given her. This plan was first introduced by Palaestrio near the beginning of the act, on 1.978 (immo uin tu lepide facere?-loquere et consilium cedo). The soldier brings up the question of how to get rid of the former mistress again on l. 1095 (beginnning the the third scene), when Milphidippa has left the to fetch her mistress (quid nunc mi es auctor ut faciam, Palaestrio, de concubina?). At this point, Palaestrio re-introduces his plan (quid me consultas quid agas? dixi equidem tibi ...), part of which is to tell the girl that her mother and sister have arrived to take her home. Palaestrio claims to have met the sister and the captain of the ship, too. After this, there is a digression on the part of Pyrgopolinices, who is eager to know what the sister and the captain look like, in search of further pleasures. With the LD in (38), Pyrgopolinices returns to the plan of getting rid of the girl on good terms. The construction serves to pick up the topic of Palaestrio's advice (consilium) on ll. 1097-1101. The consilium remains the topic until the end of the scene (1. 1136). It is also an important to the play's plot.

In Plaut. Stich. 75, LD is used to re-establishe a topic mentioned quite some time earlier:

\section{(39) Antipho}

principium ego quo pacto cum illis occipiam, id ratiocinor PLAUT. Stich. 75

'I'm considering the beginning, how I should start with them.' 
In this construction, there is no relative clause modifying principium. Instead, the indirect question quo pacto ... occipiam helps to indentify principium. The predicate ratiocinor governs both the indirect question and principium, which refers here to Antipho's plan to take his daughters back home, while their husbands remain abroad in a military campaign. The plan has been mentioned in the preceding dialogue between the two sisters on l. 14, so it is by now somewhat distant. The construction probably serves to show the prepondering state of mind of Antipho and is needed to remind the spectators of his plan.

In the following example, a simple neuter pronoun is used as a reactivating device.

(40) Palaestrio

igitur id quod agitur, $\langle$ ei $\rangle$ hic primum praeuorti decet PLAUT. Mil. 765

'Then we should give priority here to what's being done.'

Palaestrio here resumes the actual topic of the conversation between himself, Pleusicles and Periplectomenus from 1. 612. In between, there has been a long digression on various topics. The short phrase id quod agitur here constitutes a radical shift back to the topic that had been abandoned 150 lines earlier. Palaestrio goes on to explain his master plan to Pleusicles and Periplectomenus. It is to be noticed that the resumption in main clause $\langle e i\rangle$ is a conjecture. ${ }^{32}$ While not in any way surprising in view of the radical topic shift, the resulting constrution is syntactically alone in its category. There are no other examples of neuter pronouns as LD elements that are picked up by a dative in the main clause. Hence, it is possible that the conjecture cannot be trusted.

A large part of the attractions belong in this group, too. All of them show some degree of topic-continuity. In Ter. Eun. 652-653 eunuchum quem dedisti nobis quas turbas dedit, LD is used to introduce the eunuch and to establish him as the discourse topic. However, perhaps more interestingly, most of the attractions share an element of surprise connected with visual observation. We find this in Plaut. Pseud. 592, where hunc quem uideo is uttered by Pseudolus when Harpax enters the stage. In Plaut. Poen. 644-645, hunc chlamydatum quem uides refers to Collybiscus, who is on the stage but has remained unseen by the others. The line is a reaction to the question on 1.644 sed quid nunc uoltis and involves

32 By Acidalius in the 16th century, printed in Lindsay and de Melo. 
a shift to a new discourse topic. ${ }^{33}$ Sudden recognitions take place in Plaut. Epid. 448-449 istum quem quaeris ... Periphanem Plothenium and Plaut. Trin. 985-986 illum quem ementitu's. In the latter passage, the antecedent ille is established at the same time as a discourse topic. The attractions will be discussed in further detail in section 3.4. Therefore, I cite here in full only Plaut. Curc. 419:

(41) Lyco $[\ldots]$

sed istum quem quaeris ego sum

PLAUT. Curc. 419

'But I am the man you're looking for.'

This line comes from the meeting of Curculio the parasite and Lyco the banker. The encounter begins with some initial joking, and here Lyco finally identifies himself as the banker whom Curculio (here, pretending to be a slave called Summanus) is looking for. On 1l. 404-406, Curculio stated his intention (sed hunc quem quaero commonstrate si potes, inibis a me solidam et grandem ... gratiam; Lyconem quaero tarpezitam) to find the banker, and here, more than ten lines later, he gets the answer: his interlocutor is, in fact, the banker. The element istum quem quaeris is therefore highly topical. After the recognition, the topic shifts from Lyco's identity to the tablets Curculio is bringing.

In the following example, the topical element is Active but remains the topic only for the sentence where it is mentioned.

(42) LAR FAMILIARIS [...]

et hic qui poscet eam sibi uxorem senex, is adulescentis est illius aunculus, qui illam stuprauit noctu, Cereris uigiliis PLAUT. Aul. $34-36$

'And this old man who's going to ask for her hand, he's the uncle of that young fellow who violated her chastity by night during the vigil held in honor of Ceres.'

The prologue of the Aulularia is spoken by the Lar familiaris. He here provides essential information on the identity of one of the main characters. The old

33 Lehmann (1984: 351$)$ suggests that attraction itself is involved in producing the topical function. 
man from next door, hic senex, was introduced on l. 31 (hic senex de proxumo, where we can imagine the Lar pointing at the neighbour's door while saying this) as part of the Lar's plan to arrange a happy marriage for the daughter of his master. In this passage, more information is given about the old man: he happens to be the uncle of the young man who raped the girl in question and who, according to the Lar's plan, should eventually marry her. The old man does not continue as the topic, however: the Lar shifts the topic to the master of his own house (again, hic senex on l. 37, but a different one), who is shouting inside the house and closes the prologue.

\subsubsection{Re-activating an Accessible Referent or Introducing a Brand New Referent as Topic}

In the prologues of comedies, the speaker of the prologue introduces the setting and persons of the play to the audience. Several instances of LD are found in Plautine prologues (or elsewhere in the initial scenes). In these passages, the dislocated constituents refer to central persons in the story. Typically, LD is not used when the persons are initially introduced, but in the second reference, when the person, already once mentioned and introduced, is picked up again to offer some additional information.

This organization appears in the prologue of Menaechmi.

(43) Prologus

Epidamniensis ill' quem dudum dixeram

geminum illum puerum qui surrupuit alterum, ei liberorum nisi diuitiae nil erat

PLAUT. Men. 57-59

'That man from Epidamnus I was talking about a moment ago, the man who kidnapped that other twin, he had no children except for his wealth.'

After speaking on various other themes, the speaker of the prologue here returns to the merchant from Epidamnus. This merchant, who kidnapped the other twin, was first introduced on 1.32 . Here, re-established as the topic of the discussion, he is first defined by two relative clauses then referred to in the dative $e i$... nil erat. He and his subsequent actions (including death, ingressus rapidum fluuium, in the same passage) are the topic of the following lines (6o66). The merchant himself is relevant to the plot only in terms of being the abductor and adoptive father of the lost boy and is thus instrumental to separating the twins from each other.

The following lines come from the prologue of Poenulus: 
(44) Prologus [...]

ille qui adoptauit hunc sibi pro filio, is illi Poeno huius patruo hospes fuit

PLAUT. Poen. 119-120

'The man who adopted this chap as his son was a family friend of that Carthaginian, the uncle of the young man.'

This sentence establishes the connection between Hanno the Carthaginian and Antidamas, the adoptive father of Agorastocles. In the immediately preceding lines the speaker of the prologue has made a pun about his own words and before that he has been describing the actions of Hanno in his attempt to find his lost daughters. The adoptive father has been first introduced on ll. 7374 (domino hic diuiti quoidam seni, cupienti liberorum, osori mulierum). Then, on 1.119 , a relative clause is used to identify the man in question, after which the connection between him and Hanno (illi Poeno huius patruo) can be stated: he was Hanno's family friend. Note that three persons are mentioned in (44): ille qui / is, hunc/huius and illi Poeno ... patruo (in contrast with Poen. 124 hic qui hodie ueniet, without resumption; see the discussion in 3.6).

A similar organization can be found in the next example:

(45) Hegio [...]

aduorte animum sis: tu istos captiuos duos,

heri quos emi de praeda de quaestoribus,

is indito catenas singularias

istas, maiores, quibus sunt iuncti, demito

PLAUT. Capt. 110-113

'Pay attention, will you? Those two prisoners I bought from among the spoils from the quaestors yesterday, put of these separate chains on each of them and take off the heavier ones they're bound with now.'

With these lines, Hegio opens what, in modern editions, is the second scene of the first act. After the prologue, the parasite Ergasilus's long monologue has filled the first scene in act one. The captives, Philocrates and Tyndarus, are still present on stage, bound in chains. They are the topics of Hegio's short speech here (ll. 114-118), but the topic afterwards shifts.

In the following examples, LD is used to introduce a Brand New element as topic. We return first to Captiui. With the left-dislocation in (46), the two captives are introduced for the first time, in the first two lines of the play. 
(46) Prologus

hos quos uidetis stare hic captiuos duos,

illi quia astant, hi stant ambo, non sedent

PLAUT. Capt. 1-2

'Those two prisoners you can see standing here, they're both standing, not sitting, because the people back there are standing.'

The speaker of the prologue is here probably pointing to the two captives, Tyndarus and Philocrates, who are the topic of the play. They are standing in front of Hegio's house, chained together. The expression is thus used to introduce the entire play and its central theme. Nevertheless, in the main clause, the speaker of the prologue does not, in fact, continue to speak about the two captives. Instead, he connects their standing posture to the fact that some spectators are still standing at the back. He then continues introducing characters of the play, interrupting this introduction by making remarks to the audience. ${ }^{34}$

In the following example, the entity introduced for the first time in the LD construction has an essential role in the play (or at least the first part of it, after which the theme of the secret doorway is abandoned).

\section{(47) Palaestrio $[\ldots]$}

nam unum conclaue, concubinae quod dedit

miles, quo nemo nisi eapse inferret pedem,

in eo conclaui ego perfodi parietem

qua commeatus clam esset hinc huc mulieri

PLAUT. Mil. 140-143

'Well, one room which the soldier gave to his concubine, and into which no one except for herself could set foot, in that room I made a hole in the wall so that the girl would have a passage from here to here in secret.'

34 In this connection can be mentioned the beginning of the argumentum of Menaechmi (Plaut. Men.arg.1-2 Mercator Siculus quoi erant geminifilii, ei surrupto altero mors optigit). There, the Sicilian merchant is established as the starting point of the play. Three things are told about him: he had twin sons, one was kidnapped and he (the father) then died. As the Plautine argumenta were composed and added to the plays much later (probably in the 2nd century $\mathrm{CE}$ ), this construction has not been included in the corpus of republican Latin left-dislocation. It nevertheless shows the potential of LD in Latin. The construction is used to introduce a person and to predicate three things about him at once. On the other hand, the language used in an acrostich argumentum such as this one may not reflect genuine linguistic strategies. 
In these lines, Palaestrio tells us about the trick he has played to enable the secret meetings of the young lovers. He first introduces the room, unum conclaue, given to the girl by her master the soldier, and, after a further detail (that no one except the girl could enter that room), reveals what is important in the first part of the play, that he, Palaestrio, has cut a hole in the wall between the two houses (the other one belonging to Periplectomenus, an old man who is sympathetic to the lovers' case).

Several of the LD constructions occur in what are traditionally called 'running slave scenes'. In these scenes, a slave or a parasite is making hasty progress through the stage, either in pursuit of his own plans or on a mission given to him by his master. It seems that running slave scenes in Plautus contain several nonstandard syntactic phenomena. The following three examples of this type contain two LD constructions each and, in addition to them, certain other constructions of interest.

The following, one of the attractions, comes from the monologue of the slave Chrysalus at the beginning of scene nine in act four of the Bacchides:

\section{Chrysalus $[\ldots]$}

nam ego has tabellas opsignatas, consignatas quas fero non sunt tabellae, sed equos quem misere Achiui ligneum

PLAUT. Bacch. 935-936

'These tablets, which I am carrying signed and sealed, aren't tablets, but the wooden horse which the Achaeans sent.'

In this monologue, Chrysalus reveals his clever plan to the audience. In doing this, he compares the persons and other elements involved in his plan to the heroes of the Trojan War. The tabellae opsignatae that the slave is carrying with him contain a letter from Mnesilochus to his father Nicobulus in which the former asks for money to settle his dealings with a girl. Chrysalus describes the tabellae as the Trojan horse, as it is with them that he plans to trick the old man and help his young master Mnesilochus. The tablets are introduced with this phrase (thus, they constitute Brand New anchored information) and are of great importance to the plot later. The rest of Chrysalus's monologue goes on to draw further parallels between the present situation and the legendary war, Chrysalus himself playing the part of Ulysses (for a closer analysis of this passage, see 3.4 ).

The same monologue contains another LD: 
(49) nostro seni huic stolido, ei profecto nomen facio ego Ilio PLAUT. Bacch. 945

'This stupid old man of ours, I'll definitely give him the name of Ilium.'

The stupid old man whom Chrysalus here gives the name Ilium is not the topic of the following lines but is part of the more general topic of the Trojan war and the comparison of its characters with those of the present situation. The old man Nicobulus is accessible as one of the central figures of the play and is easily identifiable by the sole characterization nostro seni huic stolido. Nicobulus had left the stage after 1. 924, following which Chrysalus entered the stage and initiated his monologue.

I continue with what are, in effect, two rather similar passages: Plaut. Capt. 807-822; Curc. 288-297.

In the second scene of the fourth act of Captiui, the parasite Ergasilus is making his way through the streets to find his master Hegio and to tell him the good news: that Ergasilus has just seen Hegio's long lost son in the harbour. Ergasilus makes violent threats to people blocking his way on this happy mission and lists groups of persons he is particularly angry with (millers who keep sows and feed them on husks, fishermen who sell rotten fish and butchers who bereave sheep of their children):

\section{(50) Ergasilus}

tum pistores scrofipasci qui alunt furfuribus sues, quarum odore praterire nemo pistrinum potest: eorum si ego quoiusquam scrofam in publico conspexero, ex ipsis dominis meis pugnis exculcabo furfures

PLAUT. Capt. 807-810

\section{HEGIO}

basilicas edictiones atque imperiosas habet: satur homo est, habet profecto in uentre confidentiam

PLAUT. Capt. 811-812

(51) Ergasilus

tum piscatores qui praebent populo piscis foetidos, qui aduehuntur quadrupedanti, crucianti cantherio, quorum odos subbasilicanos omnis abigit in forum, eis ego ora uerberabo surpiculis piscariis, ut sciant alieno naso quam exhibeant molestiam 
tum lanii autem qui concinnant liberis orbas ouis, qui locant caedundos agnos et dupla agninam danunt, qui Petroni nomen indunt uerueci sectario, eum ego si in uia Petronem publica conspexero, et petronem et dominum reddam mortalis miserrumos

PLAUT. Capt. 818-822

'Next point: the millers feeding sows, who raise pigs with the husks, because of whose stench no one can go past the mill; if I see a sow of any one of them in public, I'll knock the husks out of their owners themselves with my fists.'

'He has royal and imperious proclamations; the man is full, yes he has boldness in his belly.'

'Next point: the fishmongers, who ride here on a jogging, jolting gelsing and who offer the people stinking fish whose stench drives all loafers in the arcade out into the market, I'll whack their faces with their fish baskets so that they know what a nuisance they are to the public nose. Next point now: the butchers who arrange for sheep to be bereft of their children, who arrange for the lambs to be slaughtered and then sell the meat for double the price, who call the wether followed by the flock their Petro; if I set my eyes on this Petro in a public street, I'll make both Petro and its master the most wretched of mortals.'

The insults and threats, though not important by themselves, uttered here by Ergasilus in one type of 'running-slave scene' (Ergasilus is not a slave but a parasite) appear at a crucial moment in the play, when Hegio is about to find out that his son has come back. This monologue describes Ergasilus's state of mind during his progress from the harbour to Hegio's house. He is aggressive in his eagerness to announce the happy news and to be appropriately rewarded with a feast by his master. The three groups he mentions are all treated syntactically in a similar fashion. Each group is introduced with a thematic nominative followed by a relative clause. ${ }^{35}$ The referents of these groups have not been mentioned previously and are not relevant entities in the play outside this scene. After the defining relative clause, the referent is taken up in the genitive (eorum ... conspexero) in the first group (the millers) and in the dative (eis ... uerberabo) in the second group (the fishermen). As for the third group, lanii (the butchers) is first followed by three relative clauses but is then dropped out, and,

35 See also the analysis of this passage in Adams, Lapidge and Reinhardt (2005: 16-18). 
in the main clause, the anaphoric expression is used to refer to a constituent mentioned in the second relative clause (Petro). ${ }^{36}$ This third example has not been classified as left-dislocation, because eum ... Petronem in the main clause refers back to lanii at the beginning, and the construction thus comes closer to anacoluthon than left-dislocation. Eckstein (1921: 171) notes on this passage 'Sehr geschickt verwendet Plautus die altrömische Technik, um eine Spannung zu bewirken, die auf unerwartete Weise gelöst wird'. The syntactic organization of the passage imitates the language of edicts and legal language, and this is commented on by Hegio: basilicas edictiones on 1. 811, cited above, and edictiones aedilicias on 1.823 (cf. also Ergasilus's own words on 1.803 prius edico). ${ }^{37}$ Constructions where head nouns are followed by several relative clauses and taken up in the main clause by an anaphoric expression were recognized as something that would have been at home in an aediles's edict or, more generally, in a Roman law text (on these, see chapter 4).

A similar dramatic situation with similar syntactic means is found in Curculio (lines preceding the LD in (52) quoted as well):

\section{Curculio $[\ldots]$}

tum isti Graeci palliati, capite operto qui ambulant, qui incedunt suffarcinati cum libris, cum sportulis, constant, conferunt sermones inter se drapetae, opstant, opsistunt, incedunt cum suis sententiis, quos semper uideas bibentes esse in thermopolio, ubi quid surrupuere: operto capitulo calidum bibunt, tristes atque ebrioli incedunt: eos ego si offendero, ex unoquoque eorum crepitum exciam polentarium

PLAUT. Curc. 288-295

'Then those Greeks in their cloaks, who wander around with their heads covered, who prance about stuffed with books and food baskets, who stop and palaver among each other, those runaway slaves, who stand in

36 Hahn (1964: 131 fn.) makes the same observation about the syntax of the Petro passage.

37 De Meo (1986: $71-72$ ) points out the parody of legal language in Plautus, Captiui 8o3 ff.: 'Le categorie cui l'ordine è indirizzato sono introdotte in serie, come nei paragrafi delle vere leggi, con nominativi piazzati allinizio e privi di normali legami sintattici con la principale, alla stessa maniera di certe prescrizioni legali, e con largo uso di relativi e di anaforici (...). Basta confrontare con qualcuno dei numerosi capoversi, sintatticamente quasi tutti di analoga struttura [note 9], della Lex agraria del 111 a.C. $(15+24+$ Lex Cornelia 31 uiatores praecones).' On these passages, see further chapter 4. 
your way and block your path, who prance about with their clever sayings, whom you can always see drinking in the tavern when they've stolen something; with their heads covered they drink mulled wine and prance about with a grave expression and drunk. If I meet them, I'll drive the barley-fed farts out of every single one of them.'

(52) tum isti qui ludunt datatim serui scurrarum in via

et datores et factores omnis, subdam sub solum

PLAUT. Curc. 296-297

'Then those slaves of the city bon vivants, who play ball in the street, I'll put all the throwers and players under the ground.'

Here, Curculio, another parasite, proceeds through the crowd in great haste, at the same time making disparaging remarks about Greek persons and slaves who are blocking his way without having anything of real import to attend to. He introduces both groups in nominative followed by relative clauses. The first group, isti Graeci palliati ... qui ambulant ... quod semper uideas, can be constructed as the subject of the following regular main clause, operto capitulo calidum bibunt, tristes atque ebrioli incedunt. Formally, this means that the construction is a standard sentence-initial relative clause (type $\mathrm{B} 2$ in my classification). Therefore, this example has not been included in the corpus of LD. It must be noted, however, that the description of these Greeks is so long that the subject status of isti Graeci on l. 288 (to go with bibunt and incedunt on 1l. 293294) is open to some doubt. The colon marked in the editions is one sign of this. These Greeks continue as objects in the following sentence (l. 293 eos). Again, we may quote Eckstein's (1921: 169) observation on the passage: 'Hier ist die Absicht des Dichters offenbar: Plautus will durch das Auftürmen der Relativ- und Konditionalsätze eine recht drastische Wirkung in der Schilderung der 'Graeci palliati' erreichen.'

The long characterization of isti Graeci palliati is followed by a construction that can be defined as left-dislocation, isti qui ludunt ... serui, picked up by et datores et factores omnis, which I have interpreted as a nominal resumption of isti serui, meaning that isti qui ludunt ... serui is co-referent with datores and factores (as in de Melo's translation 'those slaves ... who play ball ... all the throwers and players'). Alternatively, it could be taken as co-ordinate with isti serui (all the slaves and all the throwers and players), in which case it would not be a left-dislocation (see parallels in 3.2.4.1).

The elements introduced as topics via LD in running slave scenes are topics in only the utterances where they occur and thus do not exhibit topic- 
continuity. This is a consenquence of the function of $\mathrm{LD}$ in such contexts: to introduce new referents (or re-introduce Accessible information) effectively in the course of a single heated monologue.

There are further examples where an Active or Accessible element is promoted to topic of one to two subsequent sentences: Plaut. Poen. 64-67 sed illi seni qui mortuost, $\langle$ ei $\rangle$ filius unicus qui fuerat; Plaut. Epid. $5_{1}$ istanc quam emit; Plaut. Amph. 1009 Naucratem quem ... in naui non erat (an attraction); Ter. Eun. 951-952 uirginem istam, Thaidi hodie quae dono datast, scis eam hinc ciuem esse?

The next group contains examples where a Brand New element is promoted to topic via LD and is the topic of only its own sentence. These are often side remarks that do not otherwise relate to what is happening on stage. While the LD element is the topic of the sentence where it occurs, the conversation afterwards goes on without further mention of the detached element. These instances show that LD constructions may be used to promote topics in a variety of settings, and an LD construction does not necessarily mean that the dislocated constituent is high in topicality.

(53) Leonida [...]

sed uina quae heri uendidi uinario Exaerambo, iam pro is satis fecit Sticho?

PLAUT. Asin. 436-437

'But the wine I sold to the wine-merchant Exaerambus yesterday, has he settled with Stichus for it now?'

In this passage, the slave Leonida pretends to be the overseer Saurea and is making enquiries about several persons and their duties. Neither the uina mentioned here, nor uinarius Exaerambus were mentioned before (or are mentioned after) this scene in the play. The uina are first introduced and defined, then a question about them is expressed. ${ }^{38}$ Similar organizations are found in Plaut. Most. 840-841, where haec quae possum refers to a painting on the wall and is thus Active in the situation (with an element of contrast), Plaut. Mil. $35^{2}$ hoc quod ago id me agere oportet, referring to the slave's activity on stage, and Plaut. Most. 1046-1047 ostium quod, a Brand New element but anchored in the situation with the relative clause, just like uina quae in (53).

38 The same conversation contains scyphos ... rettulitne (1. 444), with a similar organization except that there is no resumption (type B2). 
Further examples of sentence topics (side remarks) occur in Plaut. Men. 310312 (attraction of an Accessible referent nummum illum quem), Asin. 237 (domi serui qui sunt) and Bacch. 214-215 (Epidicum quam ego fabulam), the latter of which are both Brand New referents. The reason behind LD in these constructions is probably that the element has not been mentioned before and needs to be introduced in a conscise and effective way, as it will not remain the topic, so that a more elaborate introduction of the entity in question is not dramatically motivated. The sentence is a side remark without much relevance to the on-going conversation or the play's plot. Note, however, that both examples from Asinaria and Bacchides have a nominal resumption, meaning that the combined effect of semantics and pragmatics must be assumed to be the motivation behind LD in their instances, because the nominal resumption offers extra information on the referent.

In Plaut. Pseud. 64-71 (nostri amores), we find a listing LD where syntax is clearly the most important factor for the use of resumption (with a list of Brand New elements as the dislocated constituent). ${ }^{39}$ A shorter list occurs in Most. 116o-1162, where the topical element faenus, sortem sumptumque omnem is picked up from 1. 1140, but is not topical beyond this sentence.

There are several passages in comedy where entities that are Brand New elements in the conversation seem to appear as topics (e.g., running slave scenes, as well as the sentence topics and side remarks just discussed). This raises the question of the potential for LD s to promote to topic status even elements that are new in the situation. Can new referents occur as topics in LD constructions? Brand New referents as LDs should not be possible (or the preferred strategy), at least if one agrees with Lambrecht (1994:184) that, for the receiver of the message, the mental effort of coping with the Brand New element and simultaneously receiving information about that element is no an easy task, so speakers or writers tend to avoid predicating things about entities that are new in the situation. A context where the referent of the detached element can be given a generic interpretation is an easily imaginable place for a Brand New topic, but this is not the case in the above-mentioned examples. We will have to assume that, in a fictional context, the restrictive relative clause alone was enough to identify such a referent.

We have seen that in the two running slave scenes discussed above there was a strong anchoring expression (a defining relative clause) attached to the LD element. Because of this, the constructions are not actually surprising, even

39 One more listing LD occurs in Asin. 198 (diem aquam solem lunam noctem, a generic statement). 
in the absence of a generic interpretation. In the next example, the situation is clearly different from the 'running slave scenes' discussed above. This construction does not contain a relative clause. Instead, there is an indirect question, as was also the case in (39) above:

(54) Pyrgopolinices ubi tu es?

Автотrogus eccum. edepol uel elephanto in India quo pacto ei pugno praefregisti bracchium

PLAUT. Mil. 25-26

'Where are you?' 'Look, here I am. Or take the elephant in India, how you broke its arm with your fist.'

The slave Artotrogus continues the fictitious list of Pyrgopolinices's deeds, mentioning an elephant in India whose leg the soldier broke. The elephant is definitely new to the context. However, its appearance is not as surprising as might appear at first sight. It continues the list of Pyrgopolinices's brave actions from 1.16 nempe illum dicis cum armis aureis quoius tu legiones difflauisti spiritu, quasi uentus folia au peniculus tectorium. The words edepol uel before the dislocated constituent elephanto serve to take the audience's thoughts to the discourse topic of this scene, the fake bravery of the braggart soldier. Thus, the audience is prepared to receive something completely ungrounded in the context. How to assign pragmatic functions in this sentence is not immediately evident. Is the elephant the topic, or should we rather think that this is an example of a sentence-focus structure, providing one more point in the list of Pyrgopolinices's heroic deeds, which is the general topic of this dialogue?

\subsubsection{Complex Referential Situations}

In certain examples, it seems that the primary motivation behind the use of LD is the complex situation being described and the multiple persons and things referred to. In one sense, one can say that the motivation behind LD is originally syntactic and comes from the author's wish to combine several ideas in one sentence..$^{40}$ It is probable that the complicated syntax also contributes to a comical effect.

The first example comes from Pseudolus:

40 Cf. Somers (1994: 158-159), who observes that, in Cicero's letters, resumption in thematic expressions is prompted by complex syntax in the main clause. 
(55) Calidorus quid istuc est?

PSEUDOLUS epistulam hanc modo intercepi et symbolum

CALIDORUs symbolum? quem symbolum?

PsEudolus qui a milite allatust modo

eius seruos qui hunc ferebat cum quinque argenti minis,

tuam qui amicam hinc arcessebat, ei os subleui modo

PLAUT. Pseud. $715^{-719}$

'What's that?

I just intercepted this letter and token.

Token? What token?

The one that was brought from the soldier just now. I just fooled his slave, who was carrying it with five silver minas and who was trying to fetch your girlfriend from here.'

In these lines, Pseudolus tells his master Calidorus that, by fooling the soldier's (a milite, eius) slave, Harpax (seruos qui), he has been able to procure the means for buying Calidorus's girlfriend from the pimp. This is an important turn in the play, and the syntactic construction reflects the number of facts Pseudolus has to relate: 1) the soldier, whose symbolum and letter Pseudolus has acquired, 2) more importantly, his slave, who brought the token with five silver minas to snatch away Calidorus's girlfriend and 3) Pseudolus has succeeded in fooling the slave.

Another example of a complex referential situation is the next one:

\section{(56) LyCus}

hahahae! iam teneo quid sit, perspexi modo

hi qui illum dudum conciliauerunt mihi

peregrinum Spartanum, id nunc his cerebrum uritur, me esse hos trecentos Philippos facturum lucri

PLAUT. Poen. 768-771

'Hahaha! Now I've got what this is, I've just seen through it. Those who a while ago procured that stranger from Sparta for me now have an itch in their brains about me making profit of these three hundred Philippics.'

Here, the pimp Lycus thinks he has spotted the trick played upon him; hi qui are the advocates whom Agoracles has brought to the pimp's house. The advocates and Lycus had met before, when the former had introduced the fake soldier (peregrinum Spartanum - in reality, Agoracles's slave Collybiscus) to him. The 
advocates, to which hi qui refers, are now present, but Lycus makes a point about their earlier meeting and about his suspicions that, meanwhile, the three hundred Philippics of the fake soldier have become an interest to the advocates as well (his cerebrum uritur). Several things are being predicated by Lycus: 1) here are the advocates who earlier introduced the Spartan soldier, 2) their brain is 'burning' and 3) the reason for this is that they have realized how much profit Lycus is going to make from the foreigner's money. This complex idea results in the expression where the advocates are first introduced with a thematic nominative then referred to in the dative in the following main clause.

In this section belong also two attractions: Plaut. Pseud. 526-529 (tibicinam illam; see the dicussion on Pseudolus in 3.4.4); Rud. 1064-1066 (illum quem ... lenonem, topic shift).

\subsubsection{Generic Statements}

There is a group of LD constructions that are not predications about entities present in the play but are instead general statements about human life. These make up a considerable portion of the LD constructions in comedy. It may be hypothetized that LD is one means of expressing such sententiae. It may be noted here that the frequency of correlative sentences as sententiae is notable (Probert and Dickey 2016). Lambrecht (1994: 167) also refers to the occurrence of Brand New referents as topics of generic statements.

The first example comes from Terence:

(57) Micio [...]

in uitast hominum quasi quom ludas tesseris:

si illud quod maxume opus est iactu non cadit,

illud quod cecidit forte, id arte ut corrigas

TER. Adelph. 739-741

'Human life is like a game with dice; if you don't get the throw you most want, you must show your skill in making the best of the throw which you do get.'

This wise advice is uttered by Micio as a response to his brother's shock at the turn things have taken with Micio's son. It presents a general statement about human life, contrasting illud quod maxume opus est with illud quod cecidit forte. The latter is topical in this utterance, while focus is on the latter part of the sentence (arte ut corrigas).

The following is a generic statement without a relative clause: 
(58) VIRGO

tamquam hominem, quando animam ecflauit, quid eum quaeras qui fuit?

PLAUT. Persa 638

'Like a man who has breathed his last, why would you ask who he was?'

The remaining generic statements occur in Most. 858-859; Mil.1292-1294; Epid. 166-167, Pseud. 269; Bacch. 385-387; Persa 766; Rud. 252; Stich. 119-120; Cas. 222-223; Asin. 198. In five instances, there is an element of contrast, as there is in (57): Most. 250-251; Trin. 672; Asin. 527; Truc. 742-745; Rud. 1240-1241. Not only nominal and pronominal antecedents of relative pronouns can have a generic meaning but even dislocated contituents without a relative clause, as in $\left(5^{8}\right)$ above.

\subsubsection{Contrastive Contexts}

In addition to several of the examples mentioned above, there are further instances where LD is found in a clearly contrastive context. A contrastive element can be a topic of its sentence, which seems to be the case in the following passages. Contrastiveness appears to be the main motivation behind the use of LD in these passages, the dislocated elements being contrastive sentencetopics. In the first three examples, the passage contains a contrastive pair, of which the second member is expressed with LD.

The first of these is a contrastive side remark:

(59) neque umquam quicquam me iuuat quod edo domi:

foris aliquantillum etiam quod gusto id beat

PLAUT. Capt. 136-137

'And nothing I eat at home ever pleases me. But the tiniest morsel I taste outside makes me happy.'

A topic shift takes place in (6o):

(6o) Megaronides [...]

inconciliastin eum qui mandatust tibi,

ille qui mandauit, eum exturbasti ex aedibus?

PLAUT. Trin. 136-137

'Haven't you got the man who was entrusted to you into trouble and haven't you thrown the man who entrusted him to you out of his house?' 
Megaronides, the speaker here, reproaches his friend, Callicles. The latter had been entrusted with the house and family of a common acquaintance, after his departure to Seleucia. The son of this person, now supposed to be taken good care of by Callicles, is continuing his debauched lifestyle and has, in fact, sold his father's house to the very same Callicles. Megaronides here points out that Callicles has made a victim of the young man who had been entrusted in his care (eum qui mandatust tibi) and driven out of his house the very man who had entrusted his son to him. On l. 137, Megaronides changes the topic from the son (who has been the topic of the preceding discussion) to the father, with the help of a thematic nominative: ille qui mandauit, eum exturbasti ex aedibus (topic in only this sentence or possibly the following: edepolmandatum pulchre et curatum probe).

There is marked contrast between istic scelestus and ego in the following passage:

\section{(61) Gripus}

istic scelestus liber est: ego qui in mari prehendi

rete atque excepi uidulum, ei dari negatis quicquam

PLAUT. Rud. 1291-1292

'That criminal is free; yet you refuse to give anything to me, who caught the trunk in the sea with my net and took it out.'

Toward the end of Rudens, the unfortunate slave Gripus here laments his fate by bringing up, though by himself, the important fact that it was he who had caught the trunk from the sea (and thus was the cause of the happy reunion) but that, to him, nothing has been given. Instead, the pimp Labrax, who caused all the trouble, gets to walk free.

Not all contrastive contexts contain a pair of clauses. Contrastiveness may be sentence-internal, as in Plaut. Rud. 142-143 ille qui inuitauit, nullus uenit (if it is accepted that nullus constitutes a resumption). A concluding statement with a contrastive element occurs in Plaut. Poen. 391 omnia illa quae dicebas tua esse, ea memorares mea. In Plaut. Rud. 1195-1196, the contrast is between the relative clause ego hodie $\langle q u i\rangle$ nec speraui nec credidi and the main clause is improuiso filiam inueni tamen ('I, who neither hoped for it nor believed it, even so found my daughter unexpectedly today.'). ${ }^{41}$ The passage is from Daemones's

41 In this example, $\langle q u i\rangle$ is an addition by Sonnenschein. It is printed in de Melo but not in Leo or Lindsay. The conjecture has some support from (61) above (ego qui ... ei), perhaps strengthened by the fact that they come from the same play. 
short monologue, where he praises the lucky turn in recent events. Finally, we may include in this group one of the examples without a relative clause: Plaut. Epid. 85 neque ego nunc quo modo me expeditum ex impedito faciam consilium placet. Here, the reason for the emphatic ego appears to be the change in the form of the first-person reference. Until the lines quoted above, Epidicus had been addressing himself in the second person (1. 81 quo in loco haec res sit uides, Epidice). Then, on 1. 85, he changes the reference to the first person, using ego in the nominative, even though the main clause predicate is placet. Thus, we can see that, whenever ego is used as a dislocated constituent, it expresses contrast of one kind or another (cf. Rud.1291-1292; Rud. 1195-1196; Epid. 85).

In addition to the passages quoted here, several of those included in the other pragmatic groups contain an element of contrast (Most. 840-841 haec quae possum; Ter. Heaut. 130-134 gnatum unicum; as well as several of the generic statements: Rud.1240-1241; Most. 250-251, 858;Trin. 672; Asin. 527; Truc. $742-745)$.

There is one interesting and oft-quoted passage that does not quite fit into any of the categories above. In (62), left-dislocation without a relative clause occurs at an important turn of events, in the recognition scene between Hanno and Agorastocles. In the preceding dialogue between Hanno and Agorastocles, the latter has told Hanno the names of his parents, Iahon and Ampsigura.

(62) Hanno

factum, quod $\langle$ ego $\rangle$ aegre tuli.

nam mihi sobrina Ampsigura tua mater fuit;

pater tuos, is erat frater patruelis meus, et is me heredem fecit quom suom obiit diem, quo me priuatum aegre patior mortuo

PLAUT. Poen. 1067-1071

\begin{abstract}
'Yes, which was hard for me: your mother, Ampsigura, was my second cousin; your father, he was my first cousin, and he made me his heir when he passed away: it's hard for me to be deprived of him through his death.'
\end{abstract}

In this speech, Hanno reveals what he has recently come to realize himself: Agorastocles is the lost son of his cousin. Hanno first identifies Agorastocles's mother as his second cousin. The words mihi sobrina clearly carry the focus and, hence, are placed in initial position. Afterwards, he proceeds to the father, introduced by pater tuos, then taken up emphatically: is erat frater patruelis meus. The left-dislocation is used to change the topic from the mother to the father. Hanno continues to speak about the father, who made Hanno his heir. 
After the passage quoted in (62), Hanno goes on to mention the mark that Agorastocles should have on his left arm, if he really is the son of Iahon. Note that there is no definition of the referent, as pater tuos is identifiable without further information. The focus is on the identity of pater tuos: he was the speaker's uncle.

\subsubsection{Left-Dislocation as a Focusing Device}

The preceding discussion has shown that the majority of LDs in comedy are topics of their predications. However, this should not mean that the same should automatically be presumed true for all examples. Is it theoretically plausible that a marked syntactic construction was used in Latin to encode two different pragmatic settings? In section 2.1.2, it was pointed out that there are varying views concerning the possible pragmatic functions of LD. Lambrecht (2001) has argued that LD is not, and cannot, be used to express a focus relation. ${ }^{42}$ But there is evidence to the contrary, so Lambrecht's position does not have to be accepted without further consideration. It seems that a close inspection of the Latin material points to such a broader capability of LD. In a small group of Latin examples, the best way to interpret the dislocated constituent's pragmatic function is to take it as the focus.

The first two passages come from prologues and are practically identical in their wording, even though one comes from Plautus and the other from Terence.

(63) LuXuria [...]

sed de argumento ne exspectetis fabulae:

senes qui huc uenient, i rem uobis aperient

PLAUT. Trin. 16-17

'But don't wait for me to tell you the plot of the play: the old men who'll come here will disclose the matter to you.'

In the prologue of Trinummus, Luxuria has finished telling the audience the initial setting of the play. Here, she goes on to point out that she will not detain the audience from the plot any longer. Instead, the old men soon coming on stage will provide that information. Therefore, the most natural interpretation

42 Elsewhere, Lambrecht himself (1994: 225) refers to the multiple discourse functions of syntactic structures. On topicalized constituents in English that are either focus or topic, see also Lambrect (1994: 31). 
of the pragmatic setting seems to be that the topic here is the plot of the play, argumentum fabulae. It has been established as topic in the line immediately preceding: de argumento ne exspectetis fabulae (focus on ne exspectetis). In the next line, the argumentum remains the topic (rem uobis aperient). Most salient is that it is the senes soon coming onto the stage who will tell the audience about the plot. The senes qui huc uenient, according to this interpretation, is the focus of the sentence.

\section{(64) Prologus}

dehinc ne expectetis argumentum fabulae senes qui primi uenient, i partem aperient in agendo partem ostendent TER. Adelph. 22-24

'I will not detain you from the plot of the play. Part of it will be disclosed by the old men who first come on the stage; the rest will appear over the course of the action.'

In the prologue of Terence's Adelphoe, the same phrase appears as did in the prologue of Plautus's Trinummus. In Terence's prologue, however, these words do not interrupt an account of the plot of the play, as they do in Plautus. Instead, this is simply a way to end the prologue and open the action, added to the final part of the prologue. Otherwise, the pragmatic setting is the same as in Plautus: the argumentum fabulae has been established as topic in the preceding line, and the dislocated constituent senes qui primi uenient is the focus.

The pragmatic structure of these two passages, if correctly interpreted, is one where the verbal part of the predication is topical (telling the audience about the argumentum), and the focus is on a nominal constituent. This constellation is closely related to what has been called an argument-focus structure. Lambrecht (1994: 222) identifies as an argument-focus structure a pragmatic construction in which the focus identifies the missing argument in a presupposed open proposition. This type of argument-focus is not compatible with the old model, where the topic-comment equals the subject-predicate (Lambrecht 1994: 232).

It is possible to identify an argument-focus structure in the following passage from the Menaechmi. Peniculus's line answers the question by Menaechmus. As such, it is unquestionably the missing argument in a presupposed open proposition and, consequently, an argument-focus. 
(65) Menaechmus

sed quid ais?

Peniculus

egone? id enim quod tu uis, id aio atque id nego

PLAUT. Men. 162

Men But what do you say?

PEN I? I say yes and no to whatever you wish.

'What are you saying,' asks Menaechmus, to which Peniculus replies, 'Me? Whatever you want, that's what I'll say and not say.' It is not possible to reconstruct id enim quod tu uis here as the topic and the verbal part aio atque ... nego as the focus. Saying something is topical, since that is present already in Menachmus's question.

Another unambiguous instance of an argument-focus structure can be found in the following passage from Mostellaria:

(66) Tranio sortem accipe

MISARgYRIDES immo faenus, id primum uolo

PLAUT. Most. 592

'Take the principal. 'No, the interest is what I want first.'

Misargyrides has just mentioned the money that Tranio should pay to him. Tranio offers to pay back the principal (sortem), but Misargyrides will not settle for that: he wants the interest (faenus) first. The fact that Misargyrides wants money to be paid to him is the topic of the conversation, and it is present in the verbal part of Misargyrides's line (id primum uolo). The nominal part, faenus, carries a constrastive focus with respect to sortem accipe in the preceding line.

Yet another passage where the verbal part of the predication is topical and the nominal part is focal can be seen in the following example from Stichus:

(67) EPIgnOMUs si arte poteris accubare

GELASIMUS uel inter cuneos ferreos

tantillum loculi ubi catellus cubet, id mi sat erit loci

PLAUT. Stich. 619-620

'Even the tiny space between iron bars where a puppy lies will be enough space for me.' 
Gelasimus tells Epignomus that he is able to sleep in the tiniest of places. The beginning of 1.619 expresses the topic si arte poteris accubare.

Finally, it is possible to interpret (68) from the Aulularia as expressing the same pragmatic setting (argument-focus).

\section{(68) Eunomia}

id quod in rem tuam optumum esse arbitror, ted id monitum aduento

PLAUT. Aul. 144-145

'I've come to recommend to you what I consider to be in your best interest.'

After a lenghty introduction at the beginning of act two of Aulularia, Eunomia is here finally reaching the matter she wants to discuss with her brother Megadorus - that the latter should take a wife into his house. It is by now clear that there is something Eunomia wants to tell her brother and ted ... monitum aduento is therefore topical in Eunomia's line. According to this line of interpretation, id quod can be taken as an argument-focus.

The following passage represents one instance where it is difficult to determine the distribution of pragmatic functions:

\section{(69) Hegio}

quod bene fecisti referetur gratia. id quod postulas, et id et aliud quod me orabis impetrabis

PLAUT. Capt. 941-942

'For your kindness toward us you'll receive thanks. What you're requesting, this and anything else you ask me for, you'll get it.'

Hegio here promises to fulfill Philocrates's wish to have his loyal slave Tyndarus (938-939) back. Hegio's words are emphatic, and id quod ... et id et aliud comes close to being the focus of the sentence. That Hegio will not refuse anything Philocrates asks of him has already become clear (1. 937 quid opust uerbis? lingua nulla est qua negem quicquid roges). The object, id quod postulas, is not the topic in the following context. Alternatively, one could claim that id quod postulas is the topic in this sentence and the verbal part of the main clause (impetrabis) is the focal constituent.

The informational status of the focused element is Brand New anchored in (63)-(65) and (67)-(69) and Accessible in the case of faenus in (66). 
It should be noted here that all three instances of the pattern id quod ... id express, at least potentially, a focus relation. ${ }^{43} \mathrm{~A}$ comparison with id quod without resumption in Plautus reveals that, of the four examples in the sample (see below 3.6), two express a focus relation (and constitute $2 / 4$ of the potential focus relations in that material). This raises the possibility that id quod is an expression that easily occurs in focus expressions.

\subsection{Discussion and Conclusion}

\subsubsection{Pragmatics and the Function of $L D$ in Comedy}

A clear majority of the dislocated elements in comedy are well-established entities in the discourse fragment where they appear. The most common informational status of the dislocated constituent is Active. This means that the entity in question has already been mentioned in the immediate context and is actively present as one of the potential topics in the conversation. Leftdislocation also has the potential to re-introduce Accessible referents across a distance. These observations are in line with the prediction of Lambrecht that LD is normally used to introduce Active or Accessible elements.

Interestingly, there has been observed a considerable number of left-dislocations establishing Brand New elements as topics. Two factors may influence this tendency in comedy. The first is that what we see in Plautus and Terence is, after all, fictional dialogue, which cannot necessarily be expected to obey the tendencies of genuine spoken dialogue in every respect. Indeed, I have suggested above that the use of LD to introduce a Brand New referent may have been a practical way for introducing referents that do not require a more thorough introduction in the dramatic situation where they occur. Another factor is the occurrence of relative clauses. These give a certain flexibility to the construction by allowing the anchoring of referents that are Accessible but mentioned several lines before, and even of identifying Brand New elements in dislocations.

As for pragmatic organization, on the basis of the above discussion, we can verify the hypothesis that, in comedy, this type of left-dislocation (thematic nominatives, anticipation and attraction) typically expresses the topic of the subsequent predication. Altogether, 70 out of the 77 examples of LD in comedy contain referents that are topics at least in their own sentences.

43 This is the same as the three certain examples of $i d$ quod with resumption, as id quod ... $\langle e i\rangle$ in (40) above is uncertain, possibly even unlikely given the uncertain text. 
Beyond this, LD has shown a stronger association with topics than merely establishing topics in the sentences where they occur. It has become apparent that LD is often used in the following contexts: as a way to establish as a discourse topic an element that is already actively present and even topical in the conversation, to re-activate Accessible elements across a distance, in running slave scenes as a tool for creating a hurried comical effect, to introduce Brand New referents (in side remarks), to express the topic in generic statements, to express a contrastive topic in contrastive contexts, and to express focus relations.

Despite this tendency, there remain examples where LD introduces a constituent that is the topic only in the particular sentence where it occurs. Interestingly, it seems that, in these examples, the dislocated constituent tends to be a previously unmentioned element. In other words, there is a correlation between a sentence topic and the element's informational status as Brand New anchored. This suggests that LD can be used in two different information structural and pragmatic constellations: ones where highly topical elements are established as (discourse) topics and ones where there is need to re-activate an Accessible referent that has not been mentioned for some time or to introduce a previously unmentioned element as the topic of merely one sentence, so that more elaborate ways to do this would not be justified, given the general irrelevance of the utterance. Nevertheless, in some cases, the function of LD is more conveniently analysed as a focus than as a topic.

There seem to be no discernible patterns between the syntactic form of a dislocation and the pragmatic function of the dislocated element in the discourse context. In other words, the pragmatic functions are scattered across the syntactic categories without any clusters like, for instance, 'dislocations in the nominative are generic statements'. However, there does seem to be a concentration of discourse topics among anticipations (accusative and dative), accidental or not. As for instances where both the dislocated element and the resumption are in the nominative, Rosén (1992) suggests that these should be understood as rhematicizing constructions (i.e., focus on the dislocated element). It appears that, while there are such instances, this does not hold up as a rule, at least according to my analysis of the pragmatic constellation of these passages. However, there are instances where a nominative dislocation is the focus (senes qui ... $i$ twice). Furthermore, there are several neuter dislocations with a focus function that partly represents the nominative case (id quod ... id; fel quod ... id; faenus ... id; tantillum loculi ... id). 


\subsubsection{Attractions}

It was observed above that it would seem impossible to discern a motivation in the syntactic context of attractions that would account for the use of this construction in the specific contexts where it occurs. In this section, I will attempt to explain the construction by looking in greater detail at the dicourse context and pragmatic function of these attractions.

Three attractions occur in contexts where the speaker reveals his true identity, telling his interlocutor that he is in fact the person the other one was looking for (or pretended to be himself): Plaut. Curc. 419 sed istum quem quaeris ego sum; Plaut. Epid. 448-449 sed istum quem quaeris Periphanem Plothenium ego sum; Plaut. Trin. 985-986 quia illum quem ementitus es, ego sum ipsus Charmides, quem tibi epistulas dedisse aiebas.

These three examples share the syntactic construction where the attracted element is the subject complement of the main clause ego sum. All three are emphatic in their contexts, though none is a major recognition scene relevant to the development of the plot-not, for instance, in the manner of pater tuos, is erat frater patruelis meus in Poenulus (62) above. Nevertheless, it is possible that this context of sudden and, at least from the perspective of the interlocutor, unexpected identification is one reason behind the attraction.

We may compare these attracted constructions with other instances of phrases containing quem and quaeris in Plautus: Merc. 132 ecce me, Acanthio, quem quaeris; Poen. 1045 siquidem ... quaeris adoptaticium, ego sum ipsus, quem tu quaeris. Here, Merc. 132, with the emphatic ecce me, is similar to the attractions in its pragmatic but not syntactic organization. In Poen. 1045, the main clause predicate ego sum precedes the relative clause. Hence, there appears to be no context where a sentence-initial iste quem quaeris could be compared with the attracted examples. Perhaps Plautus was simply fond of using attraction in such cases.

Three attractions have uidere as the relative clause predicate (Poen. 644-645 quem uides; Pseud. 592 quem uideo; Capt.1-2 quos uidetis). It is reasonable to suppose that these lines were uttered while the actor made a pointing gesture. It is also possible to imagine that the context in Captiui created a need for a special emphasis, given that hos captiuos opens the entire play.

Again, combinations of quem and uides/uideo are uncommon in Plautus (Cas. 213 quis est quem uides; Trin. 116 quem uides, but with uidere in a figurative sense). Most importantly, there appears to be no instance of the pattern iste/ille quem uides/uideo, which would enable a comparison with the attracted examples.

Naucratem quem opens a scene in Amphitruo, but there seems to be no discernible motivation for this attraction. 
Whatever the exact motivation (or motivations) behind the attractions, one thing can be established on the basis of the above discussion: the attraction of the antecedent (attractio inuersa) in Roman comedy is not a regular construction but a minority pattern even within the restricted evidence for LD. Internal variation in the construction makes it possible for several different motivations to be behind the construction, making it likewise impossible to find one pragmatic constellation. However, in 6 out of 12 examples, the context involves a deictic element.

\subsubsection{Distribution}

The examples of left-dislocation are more or less evenly distributed in the different comedies of Plautus. The longest comedies, Miles gloriosus, Poenulus, Pseudolus and Rudens, contain the largest number of dislocations (6 each). Other comedies with 6 dislocations are Mostellaria, Trinummus and Captiui. Menaechmi has four examples. Amphitruo, on the other hand, has only one. At a highly speculative level, one might see a connection between this and the more serious nature of Amphitruo as a tragicomoedia (according to the generally accepted conjecture at Plaut. Amph. 59). As for register differences between Plautus's comedies, Mercator has no examples of LD, and it is early-on the basis of cantica, as well as its apparently close proximity to the Greek original. The same holds true for Cistellaria. Epidicus has four examples of LD, even though it is one of the shortest plays. Not much can be said about chronological distribution. Trinummus and Captiui, which both have relatively many dislocations compared with their length, are late plays.

Dislocations are not restricted to the speech of any one character type. All stock characters can use them (adulescens, senex, ancilla, matrona, leno, lena, seruos, parasitus, meretrix).

It may, however, be worth pointing out here the eponymous slave Pseudolus, whose lines contain altogether five dislocations. Two of these (Plaut. Pseud. $592,526-529)$ belong among the twelve attractions, and the latter is notable for its complex syntax: tibicinam illam quam ... ea circumducam lenonem. In yet another dislocation (Plaut. Pseud. 716-719), I have above identified a complex referential and syntactic situation. The remaining two are the reading aloud of the letter containing a listing LD (Plaut. Pseud. 64-71) and a generic statement (Plaut. Pseud. 269). Put together, these five instances, especially the complex ones and the attraction, are, in my opinion, indicative of Pseudolus's portrayal as a creative language-user (see below on Plaut. Pseud.592).

In this connection, it is worth mentioning a curious parallelism in four of the LD examples from Trinummus. Both the adulescens Lysiteles and the senex Megaronides evidence two dislocations, of which one is a generic statement 
beginning with ille qui and another a dislocation of the anticipation type where an adulescens is established as a discourse topic. Another related observation is that both examples of ego qui (although, in one, qui is supplemented) come from Rudens (spoken by Daemones and Gripus).

The majority of dislocations are found in a dialogue. But the construction is not restricted to this obvious context. Several dislocations appear in prologues and sung or recited monodies.

\subsubsection{Is Left-Dislocation in Roman Comedy a Colloquial Feature?}

In earlier research, the prevailing view was that left-dislocation is a construction used mainly in 'Volkssprache'. Most such earlier comments were presented in connection with attractio inuersa. However, as these include constructions in the nominative, they are representative of a great part of the present corpus. Löfstedt (1933: 115) mentioned the 'volkstümliche Freiheit' of the syntax (similarly in Hofmann-Szantyr 1965: 567; on late examples, see Norberg 1943: 79). This perceived freedom in syntax usually referred to the attration itself and less to the presence of the anaphoric element. Other scholars (Bach 1888; Kroll 1912; Lehmann 1979; Hettrich 1988) have taken attractio inuersa as a reflection of arhaic syntax rather than Volkssprache. The viewpoint of these early studies is limited in comparison to those I have taken in this study. I have discussed anaphoric resumption and attraction as separate features. One should remember that attractions without resumption are only a few in number. ${ }^{44}$

Havers (1926: $215^{-216)}$ considered the isolated nominative to be an ancient phenomenon ('Wir dürfen diesem vorangestellten Nominativ uralte Verbreitung zutrauen') that is rarely found in literary texts despite being frequent in everyday conversation. ${ }^{45}$ These earlier observations were not specifically aimed at examples in comedy, so they do not address this question beyond referring to 'Volkssprache'. Havers, on the other hand, does not consider nominative + nominative combinations to be part of the isolated nominative.

I shall continue by taking a closer look at certain particularly interesting passages. The left-dislocations in Bacch. 935-936 and 945 come from a much-

\footnotetext{
44 The existence of such pure attractions (without a resumptive element) in the nominative is highly dubious.

45 Havers (1926: 216): 'Bedenkt man aber, dass bei uns diese Redeweise trozt der grossen Verbreitung in der zwanglosen Volks- und Umgangssprache doch nur verhältnismässig selten in der geschriebenen Sprache auftaucht, weil es eben so gut wie ganz an wirklich getreuen Bildern der lebendigen Rede fehlt (Behaghel Pрв. 30, 539), so wird man auch für die schriftliche Überlieferung der übrigen idg. Sprachen nicht allzuviel Belege erwarten. Es kann sich nur um ein gelegentliches Eindringen dieses Nominativs aus der lebendigen Rede des Alltags in die höhere Sphäre der Literatur handeln.'
} 
discussed passage, the monody of Chrysalus (Bacch. 925-978). This is usually considered to be a mainly Plautine composition, given its exuberant expression and length (see Barsby 1986: 169-178). Chrysalus equates the protagonists of the play and his own plans of deception to the events and heroes of the Trojan war. The composition is in long verses (mainly iambic octonari), so it was a recitative rather than an actual song (Barsby 1986: 172). Fraenkel emphasized the high register and non-parodical mood of the passage, inspired by Roman tragic language (Fraenkel 1922: 68; cf. l. 933, which echoes a tragic line, probably Ennius, Cic. Tusc. 3.44; see Barsby 1986:173). Plautus has either greatly modified the monologue that his source, Menander's Dis exapaton, had here or, alternatively, composed the whole scene himself. That much or all of the monologue is genuinely Plautine (or, in any case, from some other source than Menander) is clear from the passage's confused overall design, with a focus on vivid detail rather than a logical line of thought. ${ }^{46}$

In my view, the passage's overall composition is connected to the use of the two left-dislocations therein. Fraenkel (1922: 63) compared the song of Chrysalus to the monody of Pseudolus (Pseud. 574-593) for their similar dramatic technique. In the latter passage is found one of the attractions (Pseud. 592 ). The song (in varying metre) is written in a solemn and elevated tone, seen, for example, in the archaic perduellis and the phrase qui oculis meis obuiam ignobilis obicitur? The self-praise of the eponymous slave is thought to be typically Plautine in both form and content (Willcock 1987: 118). Pseudolus is well capable of a high-register expression (cf. his parody of tragic language in Pseud. 702-706). The implication of all this is that we should be cautious about associating left-dislocation with spoken or colloquial registers, even in the case of a cunning slave like Pseudolus.

Another interesting context for left-dislocation is what is usually called the 'running slave's speech'. There are two such passages, both of which are, in fact, spoken by parasites, not by slaves: Plaut. Curc. 280-298 and Plaut. Capt. 807-822. Both passages have been identified as imitating a praetor's edict (Manuwald 2011: 298 on Curc. 280-298; cf. Fraenkel 1922: 68 on Capt. 8o7-822). This is made explicit by Hegio at Capt. 823-824 eugepae! edictiones aedilicias

46 Scholars have debated over the constitution of the passage and presented varying views as to the authenticity and sources of the lines. It is generally agreed upon that not much of it came from Menander. Jocelyn (1969: 145), who was very sceptical of genuine Plautine elements in this passage, argued that ll. 933-936, including the attratction has tabellas quas fero, is an addition by an actor from some other piece of republican (possibly Plautine) comedy. Jocelyn (1969: 148) further argued that l. 945 (seni nostro huic stolido) is an addition by some later reader of the play. I have followed de Melo's text and consider these lines to be Plautine enough to be included in this study. 
hicquidem habet, mirumque adeo est ni hunc fecere sibi Aetoli agoranomum. ${ }^{47}$ In such instances, the register is usually elevated. ${ }^{48}$ These 'catalogue speeches' offer a vivid portrayal of Roman street life (see Fraenkel 1922: 130-134). The speaker of these passages is a person lower down on the social scale (a parasite), uttering insults to his fellow city-dwellers. This is framed by Plautus in the linguistic guise of a Roman edict. Once again, there seems to be no straighforward connection between this monologue and the manner of colloquial speech, in the sense of 'genuine spoken conversation'.

In his introductory note on Plautus's style, de Melo (2011a: lxxv) notes the following on Poen. $659 \mathrm{tu}$, si te di amant: 'But such dangling nominatives are not necessarily always colloquial; they do at least sometimes have the function of emphasizing the agent.' While de Melo's example is in vocative and therefore not considered in this study, his comment appears to be used to cover other types of 'dangling' nominatives as well. My analysis has shown that this statement is on the right track. Such nominatives, here called thematic nominatives, are not necessarily colloquial. But before proceeding with this question, I will first define what is meant here by colloquial. ${ }^{49}$ There are (at least) two senses in which this term can be used in this particular context. The first possibility is that left-dislocation is meant to imitate, in stylized fashion, constructions that were used in genuine conversation and that this is done to express register in fictional dialogues. According to this perspective, left-dislocation would be one of the indicators of a colloquial register. The second possiblity (not necessarily complementary to the first) is that Plautus used LD whenever it was linguistically motivated in a given situation, regardless of register. For a great part of the examples, the latter option appears to be preferable, because left-dislocations are found in contexts that are not especially colloquial.

Connected to this, one should note that 'colloquial' and 'emphasizing the agent' (de Melo) are not mutually exclusive. ${ }^{50}$ Left-dislocation was most prob-

47 Cf. Fraenkel (1922: 68): 'als Abschluss des rein römischen Edikts: non ego nunc parasitus sum, sed regum rex regalior', which Fraenkel cites as a parallel to the copula structure of Plaut. Bacch. 935 .

48 Cf. de Melo 2011a: lxxxv: "The register is usually elevated when Plautus imitates formal genres. Particularly frequent is legal language, as in the "edict" in Mil. 16o-165; parodies of tragedy, as in Pseud. 702-706; and "running slaves' speeches" as in Curc. 280-298, which originate in the typical messengers' speeches of tragedy.' See also de Melo 2011b: 333-334. A notably difficult term in the Latin tradition; see Dickey and Chahoud 2010.

50 In the same vein, Adams, Lapidge and Reinhardt (2005: 19-20) delineate three categories of nonstandard language use: 1) colloquial or informal 2) 'irregular' constructions that are functional in the context and 3) 'bad writing', lapses, etc. To me, this classification is artificial, because the categories are on different levels of linguistic processes. The second 
TABLE 25 Types of head-internal relative clauses in comedy

\begin{tabular}{lccc} 
Construction & Plautus & Terence & Total \\
\hline A1 (qui homo ... is) & 22 & 10 & 32 \\
A2 (qui homo ... Ø) & 23 & 15 & 38 \\
Total & 45 & 25 & 70
\end{tabular}

a The occurrences of type A1 have been listed in 3.2.2.2 above.

ably used in colloquial language to 'emphasize the agent', or to introduce the topic of the sentence, to employ the terminology and viewpoint of this study. There is probably a difference here among the different types of LD. Generic statements and possibly part of the id quod ... id or other neuter pronominals are not necessarily colloquial in any sense. But some of the dislocations are colloquial, in the sense that they were available for Plautus as patterns used in actual conversation in his day and thus useful sources of stylized expression in certain contexts of dramatic dialogue.

Sometimes, LD seems to have been used more consciously, as it were, to create an impression of a confused, comical and possibly even idiosyncratic idiom, as in the case of Pseudolus. However, the constructions used by Pseudolus, as well as several other dislocations in Plautus, betray a certain amount of length and complexity. This is not the prototypical colloquial sentence.

\subsection{Information Structure and Pragmatic Organization of Head-Internal Relative Clauses (A1 and A2)}

Here, I present a short description of the head-internal relative clause in both authors. As we can see from table 25, the head-internal relative clause occurs infrequently.

The head-internal relative clause with resumption (A1) typically expresses the topic of the sentence where it occurs. In this sense, it is similar in use to leftdislocation. The head-internal relative clause is not, however, used to introduce a discourse topic. The largest part of the examples are sentence topics and other side remarks; topic continuity beyond this is found, e.g., in Plaut. Cist. $675^{-677}$;

category (functional 'irregularity', such as left-dislocation) necessarily overlaps with the first (colloquial and informal language). 
Plaut. Most. 416-418; Ter. Heaut. 654-655. It appears that, in both Plautus and Terence, half of the A1 occurrences have a generic reference (Plautus 11/22 and Terence $4 / 10$; altogether, $15 / 3^{2}$ ). This is clearly more than the share of generic statements in the corpus of $\mathrm{LD}(17 / 77)$.

It can be seen from table 25 that Terence more often leaves resumption out from a head-internal relative clause. Type A2 can also express a sentence topic and generic sententiae. It is noteworthy that Plautus has nine such generic statements with qui homo in group A2 and five examples in A1.

Another question, then, concerns the differences between types A1 and A2that is to say, in the use of resumption with the head-internal relative clause. The answer to this question may not be easy to find, as can be seen from the following examples:

(70) quoi homini dei sunt propitii, lucrum ei profecto obiciunt PLAUT. Curc. $531^{51}$

(71) quoi homini di propitii sunt, aliquid obiciunt lucri PLAUT. Persa 470

'If the gods are well disposed toward someone, they throw some profit his way.'

In this pair of examples, trying to search for a syntactic, semantic or pragmatic determining factor for the use or omission of the pronoun would probably be pointless. $^{52}$

\subsection{Comparison of LD with Sentence-Initial Relative Clauses without Resumption in the Matrix Clause (B2 and C2)}

Constructions where a combination of an antecedent and a relative clause occur in sentence-initial position, followed by a resumptive pronoun in the matrix clause, have been described in this work as left-dislocation. The standard construction, as it were, is one where there is no such resumption. These have been labelled as types B2 and C2 in this this study (see 2.2.2). Therefore, it is, in effect, the presence of the anaphoric element that differentiates

51 Also note Plaut. Curc. 557 quoi homini di sunt propitii, ei non iratos esse puto.

$5^{2}$ Note, however, the difference in word order of sunt propitii vs. propitii sunt. 
left-dislocation from the standard construction. Given that left-dislocation is assumed to be pragmatically motivated, the question one cannot help asking concerns the difference between LD and the standard construction without any anaphorics in the matrix clause. To say that LD has a certain pragmatic function implies that the corresponding standard construction has less, or a different type, of such a function.

Should it turn out that no difference can be observed between preposed relative clauses with resumption (B1 and $\mathrm{C}$, left-dislocation) and those without resumption (types B2 and C2), the conclusion must be that the practice of adding pronouns is accidental and that the existence of left-dislocation in the form described in this work can be challenged. If no difference can be discerned, one would also need to accept that the anaphoric pronouns are there merely as part of the relative clause formula, triggered by the presence of the sentence-initial relative clause and having little or nothing to do with pragmatic motivation..$^{53}$

So far, this question has not been asked about left-dislocation in Latin. The following discussion must therefore be taken as a tentative first attempt to clarify the matter. However, it is only reasonable to expect that there will be some overlap between the examples and that a difference in the construction, context or function cannot be discerned in all instances.

I begin by taking a closer look at the alternation of left-dislocation (B1 and C1) and constructions without resumption (B2 and C2) in the prologue of Plautus's Poenulus. The first pair of sentences comes from the beginning of the prologue.

sed illi seni qui mortuost, $\langle$ ei $\rangle$ filius

unicus qui fuerat ab diuitiis a patre

puer septuennis surrupitur Carthagine,

sexennio prius quidem quam moritur pater. quoniam periisse sibi uidet gnatum unicum,
'But as for that old man who died, the only son he has is kidnapped from his wealth and from his father from Carthage as a seven-year-old boy, six years before his father dies; when he sees that his only son was lost,

53 Cf. Pinkster (forthc. chapter 18): ‘[A] noun phrase that consists of a head noun and a restrictive relative clause can be determined by determiners like hic or ille. This combination may be referred to with a resumptive pronoun which indicates the function of the preceding noun phrase in the main clause, usually the anaphoric pronoun is.' 
conicitur ipse in morbum ex aegritudine:

facit illum heredem fratrem patruelem suom,

ipse abit ad Accheruntem sine uiatico.

ille qui surrupuit puerum, Calydonem auehit,

uendit eum domino hic diuiti quoidam seni

cupienti liberorum, osori mulierum. he himself falls ill from grief.

He makes that cousin of his his heir and he

himself goes to the Underworld without any travel provisions.

The one who kidnapped the boy takes him to Calydon and sells him to a certain rich old master here who wants to have children but hates women.'

Plaut. Poen. 64-74

Here, the initial sentence contains a left-dislocation. The dislocated constituent, illi seni, picks up alter est emortuos, from 1. 61. It is therefore an Active element in the discourse. This old man is the topic of the LD construction and continues to be the topic for two sentences afterwards (quoniam ... uiatico). Plautus then talks about the person who kidnapped the boy and whose existence can be inferred from surrupitur on l.66. Ille qui is the topic of the sentence here but is dropped afterwards, as the prologue moves on to tell the audience more about the old man who bought and adopted the kidnapped boy. Thus, whereas both preposed relative clauses pick up Active or Accessible entities, the one with LD enjoys longer topic-continuity.

Later on in the same prologue, another interesting pair of sentences appears:

ille qui adoptauit hunc sibi pro filio,

is illi Poeno huius patruo hospes fuit

[is hodie huc ueniet repetietque hic filias

et hunc sui fratris filium, ut quidem didici ego.

ego ibo, ornabor; uos aequo animo noscite]

hic qui hodie ueniet reperiet suas filias

et hunc sui fratris filium

PLAUT. Poen. 119-125
'The man who adopted this chap as his son was a

family friend of that Carthaginian, the uncle of the young man.

[Today, he'll come here and find his daughters

here and his nephew, as I've

learned. I'll go and

get into my costume; you must get

to know the play with goodwill.]

The man who comes today will find his daughters

here and his nephew.' 
In this case, ille qui adoptauit ... is does not exhibit topic continuity, since the following sentence (excluding the three lines removed in Lindsay) is about the Carthaginian (illi Poeno), not about the adoptive father. Therefore, topic continuity is not the reason behind the dislocation. Instead, the motivation for this construction can be found in the preceding context and information structure. It is clear that the adoptive father must be identifiable at this stage to the audience from the characterization ille qui adoptauit. However, we must look farther back in the prologue to find where this person has been mentioned last. This is, in fact, on l. 73, where he was first introduced. Accordingly, ille qui on 1.119 picks up the adoptive father from a rather long distance. Above, it was suggested that a long gap following the last mention is a triggering factor for the use of LD, which was seen to be an adequate tool for re-introduction back into the discourse. We may contrast this with hic qui hodie ueniet on l.124, which picks up illi Poeno from l. 120 (the preceding line, if Lindsay's deletion is accepted). In this case, the topic of the sentence ceases to be the topic after this sentence, so there is no motivation either for a dislocation in the subsequent context.

These observations lend additional support to the suggestion expressed earlier in this chapter, that LD can be motivated by either the preceding or the subsequent context. The motivation can be found in the preceding context if the dislocation picks up an element across some distance or even a previously unmentioned entity (Brand New anchored). Topic-continuity can be a motivating factor for $L D$ in the subsequent context.

Further evidence for the potential of left-dislocation to introduce previously unmentioned entities can be found in the following example, the beginning of Phaniscus's monologue (and the beginning of act four in modern editions). The monologue opens with generic observations on different types of slaves. The first group is introduced by serui qui, taken up by $i$ on the following line. The second group is introduced by illiqui, without resumption, presumably because the topic of slaves has already been introduced and is therefore no longer new to the discourse.

PHANiscus

serui qui quom culpa carent tamen malum metuont,

i solent esse eris utibiles.

nam illi qui nil metuont, postquam sunt malum meriti,
'Those slaves who fear a thrashing even when they're free from guilt are generally useful to their masters; those who don't fear anything, 


$\begin{array}{ll} & \begin{array}{l}\text { even after deserving a } \\ \text { thrashing, are } \\ \text { seeking stupid counsel for } \\ \text { stulta sibi expetunt consilia: }\end{array} \\ \text { themselves. They } \\ \text { practice running and flee, } \\ \text { but when they're } \\ \text { sed i si reprehensi sunt, } & \begin{array}{l}\text { caught and brought back } \\ \text { they get private } \\ \text { faciunt de malo peculium quod nequeunt }\langle\text { de bono }\rangle .\end{array} \\ & \begin{array}{l}\text { funds in the shape of beat- } \\ \text { ings, which they couldn't } \\ \text { get in the shape of tips.' }\end{array}\end{array}$

PLAUT. Most. $858-863$

It seems that the same strategy of introducing a pair of generic referents, the first one with resumption and the second one without, can be found in the following passage.

\section{(75) Lysiteles [...]}

minus placet magis quod suadetur, quod dissuadetur placet quom inopia est, cupias, quando eius copia est, tum non uelis ille qui aspellit, is compellit; ille qui consuadet, uotat

PLAUT. Trin. 670-672

'You like less what you're more advised to do, you like what you're advised against; you're keen when there's no possibility; the man who drives you off forces you into it, the man who recommends it forbids it.'

The left-dislocation is part of a longer passage where pairs of contrastive generic statements are listed. On 1. 672, the personal reference changes from a generic second person to ille. In the first reference to generic ille qui, it was picked up by is in the main clause, whereas, in the second part of the statement, ille qui is used without resumption. This can tentatively be linked to the familiarity of the construction on the basis of the previous sentence. ${ }^{54}$

In the next section, I carry out a comparison between left-dislocation as described above (B1 and $\mathrm{C} 1$ ) and preposed relative clauses where no resump-

54 Note, in this connection, without a generic reference but with an autonomous relative clause in the second part, similarly the part of the list in Plaut. Asin. $5^{27}$ illos qui dant, eos derides; qui deludunt deperis. 
tive element occurs in the subsequent matrix clause. Of the type homo qui ... $\emptyset$ (type B2 in my classification), there is, e.g., puer ille quem ego laui, ut magnust et multum ualet (Plaut. Amph. 1103), and, of the type ille qui ... Ø (type C2 in my classification), e.g., ille qui illas perdit saluos est (Plaut. Asin. 637). The material has been assembled by collecting all preposed relative clauses introduced by qui, quem, quo, quae, quam, qua, quod, quas, quos, quoi and quoius in four of Plautus's comedies (Amphitruo, Asinaria, Mostellaria and Pseudolus) using the Brepols Library of Latin Texts database. This search yielded the following results: 13 preposed relative clauses without resumption in Amphitruo, 9 in Pseudolus, 10 in Asinaria and 4 in Mostellaria. ${ }^{55}$ This forms a corpus of 36 examples of preposed relative clauses where the antecedent of the relative pronoun is not picked up by a resumptive element in the main clause. ${ }^{56}$

In this connection, a distinction should be made between case agreement and case disagreement in the dislocated element and its main clause reference. We may assume that the role of the resumptive element in the matrix clause is more substantial and that the resumptive element is less likely to be left out in instances where the dislocated constituent does not agree in case with the main clause resumption. We have seen that, excluding attractions, there are only two examples where resumption is left out where it would disagree in case with the dislocated element (noun or pronoun).

Accordingly, I have excluded from this comparison left-dislocations where the dislocated element and the resumptive element disagree in case. This means that only those dislocations where the dislocated constituent and the matrix clause resumption show agreement are taken into account. Instances of left-dislocation with case agreement make up sligtly less than half of the examples from Plautus with relative clauses, altogether 29 examples (see above subsections 3.2.1.1 and 3.2.1.2 for these). Note, however, that the relative pronoun can have a different case from that of the antecedent. Constructions without a relative clause have been left out of this discussion, as the following comparison has been carried out to determine which factors are relevant to relative clause syntax.

The first observation that can be made is that, on average, the B2 and C2 types occur more frequently in Plautus than does left-dislocation. Bertelsmann

55 Amph. 30, 138, 179, 231, 534, 546, 553, 820, 869, 884, 1101, 1103, 1139; Asin. 64, 137, 199, 271, 331, 539, 637 (bis), 662, 715; Most. 211, 274, 409, 86o; Pseud. 72, 281, 313, 356, 404, 427, 737, 910, 932.

$5^{6}$ As with left-dislocation, I have excluded addresses of the interlocutor and answers to questions that do not have a main clause. 
TABLE 26 Pragmatic function of antecedents of relative pronouns in types $\mathrm{B} 2$ and $\mathrm{C} 2$

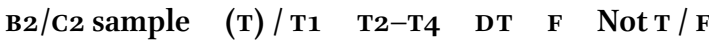

$\begin{array}{llllll}36 & 24 & 4 & 2 & 4 & 2\end{array}$

TABLE 27 Pragmatic function of antecedents of relative pronouns in types $\mathrm{B} 1$ and $\mathrm{Cl}(\mathrm{LD})$ with case agreement

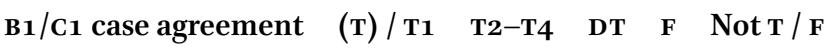

$\begin{array}{llllll}29 & 16 & 4 & 5 & 4 & 0\end{array}$

(1885: 45) gives the figure of approximately 200 instances of preposed relative clauses without resumption in Plautus (including both nominal and pronominal antecedents) and approximately 80 instances in Terence. For Plautus, this would mean approximately ten for each of the entire plays. This number does not stand in contradiction with the results of my check (36 from four plays).

The first thing to be looked at is the topical status and possible topic continuity of these examples (types B2 and c2). To enable a more refined comparison of topic-continuity, I have assigned a topic continuity value for each of the examples. There are three categories of topics: first, $(\mathrm{T})-\mathrm{T1}$ denotes a sentence topic or a topic that continues one sentence after the dislocation construction; second, T2-T4 denotes a topic continued for two to four sentences after the dislocation; third, DT (discourse topic) denotes a topic that continues for more than four sentences. A fourth category $(\mathrm{F})$ is formed by elements that are focused in their sentences and a fifth $(\operatorname{Not} \mathrm{T} / \mathrm{F})$ by those that are neither topical nor focal.

The figures here are small, so no clear difference can be established (see tables 26 and 27). It should be noted, however, that the differences are consistent in that, in the left-dislocation group (B1/C1), topic continuity is higher overall. There are fewer $(\mathrm{T})$ and $\mathrm{T} 1$ types and more $\mathrm{T} 2-\mathrm{T} 4$ and $\mathrm{DT}$ types in $\mathrm{B1} / \mathrm{C1}$ than in B2/C2. However, it is clear that no conclusions concerning the difference between these two can be made on the basis of this comparison.

Next, the information structure of the passages is outlined in tables 28 and 29. Here, although the figures are again small, a difference can be discerned in the information status of the referents. In the left-dislocation group, the share 
TABLE 28 Information structure in types B2 and C2

B2 / c2 sample Brand New Anchored Accessible / Active

$36 \quad 5$

TABLE 29 Information structure in types B1 and C1 (LD)

B1 / C1 case agreement Brand New Anchored Accessible / Active

29

12

17

of Brand New anchored (BNA) elements as antecedents of relative pronouns is clearly higher than in the group without resumption. Generic statements occur in both groups.

None of these pieces of evidence (analysis of $(72)-(75)$ above and the figures in tables 26-29) is decisive alone. However, by combining them, it is possible to provide further support for the suggestion that the use of left-dislocation can be triggered by either the preceding or subsequent context. BNA status in the information structure, a long gap since the previous reference, or topic continuity in following context all seem to be factors that increase the possibility for a resumptive pronoun to be added in the postponed matrix clause, when the two references agree in grammatical case.

Thus, syntactic, semantic and pragmatic factors can all influence the use of LD. However, it should be noted that the process of building a linguistic expression is one of overall composition and integration. It is not a matter of first choosing one part or construction then accomodating the subsequent ones to it but rather a process in which all parts are chosen at more or less the same time to produce an expression that suits the purpose and context. It is therefore possible to explain the use of left-dislocation but impossible to predict it.

\subsection{Appendix on LD in Lucretius}

In this final section of chapter 3, I analyse left-dislocation in Lucretius. There are altogether five examples. These have been described as examples of anacoluthon (Bailey 1947) and as reflections of colloquial syntax (Reinhardt 2010: 212). By comparing them with the material from comedy and setting them in 
the syntactic and pragmatic framework developed earlier in this chapter, it will be possible to describe the constructions in greater detail and offer plausible explanations for their use. Examples from Lucretius are taken from Bach (1888), Hiden (1896) and Bailey (1947). The style of De rerum natura varies considerably from passage to passage, combining archaizing, poetic and colloquial tendencies (for a general discussion, see Reinhardt 2010: 203-205; features and examples can also be found throughout the article). Lucretius's style permits features not accepted by the later classical poets (Reinhardt 2010: 203).

The first example is of a familiar type. There is a nominal element (offcium) with an attached restrictive relative clause (quod corporis exstat) and a resumption with the anaphoric element occuring in the main clause (id). Both references are in the nominative. I cite here also the preceding lines to give the necessary context for the construction.

(76) qua propter locus est intactus inane uacansque.

quod si non esset, nulla ratione moueri

res possent; namque officium quod corporis exstat,

officere atque obstare, id in omni tempore adesset

omnibus

LUCR. 1.334-338

'Therefore, there is intangible space, void, emptiness. But if there were none, things coud not in any way move; for that which is the province of body, to prevent and to obstruct, would at all times be present to all things. 57

This passage contains the first of Lucretius's arguments, to the effect that, in the universe, there is void and emptiness. The quality of the body (corpus) as a solid mass that, without a void, would not allow any movement in the world is the central idea in this part (1l. 329-345), mentioned both at the beginning (329 nec ... corporea stipata tenentur omnia natura; 345 undique materies quoniam stipata fuisset). The left-dislocation construction continues the thought of the previous sentence, quod sinon esset, and is, in this sense, parallel to nulla ratione moueri res possent. The topic of the sentence is officium corporis, which, together with and placed in opposition to the concept of void, is also the topic of the whole passage. This pair has been mentioned previously on 1l. 329-330 (nec tamen undique corporea stipata tenentur omnia natura; namque est in rebus

57 Translations of Lucretius come from Rouse and Smith (1975). 
inane). In between, on ll. $33^{-}-333$, there is a short digression, and the topic of emptiness is resumed on $l .334$ with qua propter locus est intactus inane uacansque and the following argument: quod si non esset. ${ }^{58}$ Then, on 1.336 , the idea of a corporeal body and its abilities is resumed with officium quod corporis exstat. The main clause id in omni tempore adesset omnibus is a predication about officium corporis. It continues as the topic (together with its counterpart, emptiness) until l. 345. The discussion about the nature of things that look solid (and, thus, that are close to corpora) continues even after this.

The next group of constructions has been analysed as nominative in anacoluthon (Bailey 1947: I 89). However, by describing them in terms of leftdislocation, a better analysis can be achieved. It appears that it is not really anacoluthon that is notable in Lucretius's style but left-dislocation.

Bailey (1947: I 89, nominative in anacoluthon in the Prolegomena) notes the following: 'It may be that in each of these long sentences Lucretius started his sentence in the nominative and either intended to continue so (cf. iii. 1013 qui neque sunt usquam), or liked the feeling of the nominatiuus pendens. Scansion here was probably not a deciding element, as the accusative could have been written just as well.' What Bailey here speculates is Lucretius's motivationthat he 'liked the feeling of the nominatiuus pendens' — can be given a more accurate interpretation with the help of pragmatic analysis.

(77) seruitium contra, paupertas, diuitiaeque, libertas, bellum, concordia, cetera quorum aduentu manet incolumis natura abituque, haec soliti sumus, ut par est, euenta uocare LUCR. 1.455-458

'Slavery, on the other hand, poverty and riches, freedom, war, concord, all else which may come and go while the nature of things remains intact, these, as is right, we are accustomed to call accidents.'

Here, Lucretius continues defining the nature of things. Besides bodies and void, there is no third type of basic nature; the rest are either properties or accidents of these two. Lucretius first defines properties (451-452): coniunctum est id quod nusquam sine permitiali discidio potis est seiungi seque gregari. Then, in (77), he turns to horum euenta, from l. 45o. In this way, although the

$5^{8}$ See Bailey (1947: I 166 and II 654) on the suspension of thought in this passage, and defending the authenticity of 1.334 . 
concepts listed in the left-dislocation have not been mentioned earlier in this discussion, they are not completely unexpected either. The correct interpretation, that what is now following belongs to euenta, is made explicit by the adversative contra, which comes right after the first concept, seruitium. The actual statement to this effect comes on 1. 458: haec soliti sumus, ut par est, euenta uocare. In this passage, the list making up the dislocation comes closer to being a focus constituent than a topic. It seems that the topic here is coniuncta ('properties') and euenta ('accidents'), and what these are in practice is the focus. This is clearly the organization of the first part, where coniunctum est id quod is followed by the relevant examples, and, here, although the linear order is reversed, the pragmatic organization appears to be the same. Used this way, left-dislocation allows Lucretius to build a chiastic sequence in his definition of properties and accidents.

Reinhardt (2010: 212) observes that this construction (a list and a resumption) bears resemblance to patterns of spoken discourse in modern languages and can therefore be taken as a syntactic colloquialism. While it is true, as pointed out in the preceding chapters, that left-dislocation has a strong association cross-linguistically with colloquial and spoken language, it is not necessarily a sufficient explanation for its appearance in this passage in Lucretius or in other similar passages. I argue rather that left-dislocation is a practical device in certain types of communicative situations and that it depends on the author's conception of literary style and written standard and on whether, and to what extent, such constructions are deemed acceptable in the particular context.

Example (77) has parallels in comedy (see (30) above). In my view, the difference between permissiveness and conscious selection (Reinhardt 2010: 207) of features is not the point here. I believe that, in a literary text (as opposed to a documentary one), all features are in place, because they have been consciously selected. Nothing is there simply because of a permissive accident. The notion of a permissive style relates to the line between what is accepted and what is not. In later poetry (and prose), this dividing line delineated a smaller and more tightly defined (and, in any case, different) selection of features than it did earlier. Lucretius's permissiveness is a matter of the consciously selected group of features being larger than (or different from) that of the later era.

The following example is similar to $(77)$ in that the dislocated constituent is a long list of entities.

(78) praeterea genus humanum mutaeque natantes squamigerum pecudes et laeta armenta feraeque, et uariae uolucres, laetantia quae loca aquarum concelebrant circum ripas fontisque lacusque 
quorum unum quiduis generatim sumere perge, inuenies tamen inter se differre figuris

LUCR. 2.342-347

'Moreover, the race of men, and the dumb swimming tribes of scaly fish, fat cattle, and wild beasts, the different birds which throng the joyous regions of water around bank and spring and lake, and which crowd the pathless woods through and through as they flit about — of these go on to take any one in any kind, and you will find nevertheless that each differs from each in shape.'

Here, Lucretius describes the multitude and limitless variety of things. He gives

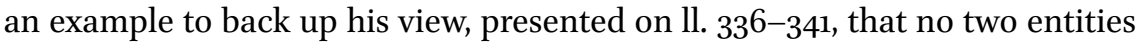
in nature are similar in form. The dislocated list of elements is followed by a relative pronoun in the genitive, but we notice that the construction is not of the relative clause type seen in Plautus, as quorum here does not introduce an adnominal relative clause but is a constituent of the main clause (attribute of the object unum) and an instance of relative connection. In fact, the dislocation here is not followed by resumption at all in the traditional sense. Instead, it is followed by two paratactically adjoined main clauses. How to assign pragmatic functions here is not obvious. I prefer to interpret the list as the topic and unum quiduis as the focus. The differing nature of things is also topical here (cf. 1l. 340-341 debent nimirum ... pari filo similique adfecta figura), so inuenies tamen inter se differre figuris cannot be the focus. ${ }^{59}$

In (79), the organization is similar to (78) in that the dislocated constituents are followed by a sentence where no resumptive element appears to take up the dislocation in the manner we have seen in comedy. As above, the first part of the sentence can be interpreted as having a relative connection.

(79) principio caeli clarum purumque colorem, quaeque in se cohibet, palantia sidera passim, lunamque et solis praclara luce nitorem; omnia quae nunc si primum mortalibus essent,

59 The passage is usually thought to be corrupt, but Bailey (1947: II 861) defended this text against seeing here a lacuna. He argued that praeterea here 'connects the a priori argument of $338-341$ with the a posteriori proof from experience. The mss reading should therefore be retained and neither emendations nor a lacuna are required.' Something similar to (78) may originally have been at Lucr. 4.123. 
ex improuiso si sint obiecta repente, quid magis his rebus poterat mirabili dici aut minus ante quod auderent fore credere gentes?

LUCR. 2.1030-1036

'In the first place, consider the clear and pure colour of the sky, and all that it contains - the travelling constellations, the moon and the bright light of the dazzling sun; if all these were now revealed for the first time to mortals, if they were thrown before them suddenly without preparation, what more wonderful than these things could be named, or such as the nations would have less dared to believe beforehand?'

Thus, we see that, concerning its overall structure, this construction has several parallels in Lucretius. What remains exceptional in this example is the accusative case of the dislocation. It is difficult to see from where the accusative derives. There is no verb that could directly govern the accusative case. In the preceding context, the verb mirarier (l. 1029) can be taken to be the mentally even if not syntactically governing verb here. However, principio undoubtedly marks the beginning of a new sentence. Another option is to derive the case from the following context, where, albeit the grammatical subjects of sint obiecta, they are the psychological objects of throwing and seeing.

Bailey (1947: II 962-963) again defends the transmitted text against corrections made by earlier editors. He does note, however, that the construction is not commonplace: 'But there is no real difficulty in the anacoluthon though accusatives picked up by nom. are more remarkable than the reverse process in the parallel passages.' 60

Example (80) occurs in a list of examples of phenomena illustrating that what the eyes see cannot be trusted (although, as Lucretius reminds us, it is not a fault of the eyes but of the mind).

(8o) extantisque procul medio de gurgite montis classibus inter quos liber patet exitus ingens, insula coniunctis tamens ex his una uidetur

LUCR. 4.397-399

6o On l. 1031, cohibet is a conjecture by Lachmann, accepted in Bailey 1947 (oQ have cohibent, in which case sidera would be the subject), but this does not affect the construction under discussion. 
'And mountains that stand up afar off from the midst of the ocean, between which is a great channel wide enough for a fleet to pass freely through, these nevertheless seem to be joined into a single island.'

In the list where (80) originates, the first example is a ship that seems to stand still while moving (and the other way around). The second example consists of stars, the sun and the moon, which do not seem to be going anywhere, even though we know that they move across the sky. The ship is introduced with qua uehimur naui (1. 387) and the stars with sidera cessare ... uidentur (ll. 391-392), followed by solque ... manere et luna uidetur (l. 395).

The mountains are here taken to be in accusative, following Bailey (1947) and Martin (1969): extantisque ... montis. The accusative case is here an attraction of the antecedent, caused by inter quos. The mountains are taken up in the subsequent main clause by ex his coniunctis. Syntactically, then, this construction can be analysed as an attraction of the antecedent, the type seen in comedy (extantis montes inter quos, ex his coniunctis uidetur insula una), with the dislocated constituent in the accusative affected by the relative pronoun inter quos. The resumption in the main clause is made by $e x+$ ablative. The closest syntactic parallel to this construction is Plaut. Pseud. ${ }^{226-529}$ (tibicinam illam quam ... ea [abl.] $)^{61}$

The list of which (8o) is a part is opened by a restrictive relative clause with an internal head (qua naui), which is picked up as the subject of the predicate fertur (no overt resumption). In the second example, the topics sidera, sol and luna appear as subjects. The mountains in (80) are then introduced in the accusative with the participial apposition extantisque, followed by a relative clause with quos and finally picked up by ex his. The phrase has even been emended to do away with the hanging accusative. ${ }^{62}$ We see in this passage

$61 \quad$ Bailey (1947: III 1231): 'extantis ... montis: Giussani, Merrill, and Ernout try to get rid of any grammatical difficulty by saying that the construction is inter quos montis ... exstantis ... liber patet exitus, ex his tamen coniunctis insula una uidetur. But I agree with Munro that there is something of an anacoluthon, exstantis ... montis being placed first to give it emphasis as the subject of discussion, though it should be taken as an accusative not a nominative. It is not so violent as the example which he quotes from Cic. De Fin. iii. 3 . 11 ceterae philosophorum disciplinae ... eas nihil adiuuare arbitror, or as the examples in Lucr. ii. $342 \mathrm{ff}$., iv. $123 \mathrm{ff}$. It is certainly a mistake to "emend" to exstant usque, Lachmann, or existuntque, Purmann.'

62 Cf. Godwin comm. ad loc.: 'extantesque is grammatically difficult, and has either been emended (Lachmann's extant usque) or explained away. Bailey is, however, right to see the sentence as something of an anacoluthon-the mountains float in glorious isolation in grammar as in life, only being drawn together into the structure of the sentence in 399 when we see them coniunctis to form an insula.' 
nicely how left-dislocation can be used side by side with other constructions in the same function (topic-promotion): relative clauses without dislocation (as in qua ... naui) and simple explicit subjects (as in sidera ... uidentur and solque ... et luna uidetur).

The mountains are a topic of their predication and, in a way, can be described as contrastive topics in the list of phenomena where they appear. 